\title{
Emotional and behavioural difficulties in children and adolescents with hearing impairment: a systematic review and meta-analysis
}

\author{
Jim Stevenson • Jana Kreppner • Hannah Pimperton • \\ Sarah Worsfold • Colin Kennedy
}

Received: 17 November 2014 / Accepted: 16 February 2015 / Published online: 11 March 2015

(C) The Author(s) 2015. This article is published with open access at Springerlink.com

\begin{abstract}
The aim of this study is to estimate the extent to which children and adolescents with hearing impairment (HI) show higher rates of emotional and behavioural difficulties compared to normally hearing children. Studies of emotional and behavioural difficulties in children and adolescents were traced from computerized systematic searches supplemented, where appropriate, by studies referenced in previous narrative reviews. Effect sizes (Hedges' $g$ ) were calculated for all studies. Meta-analyses were conducted on the weighted effect sizes obtained for studies adopting the Strength and Difficulties Questionnaire (SDQ) and on the unweighted effect sizes for non-SDQ studies. 33 non-SDQ studies were identified in which emotional and behavioural difficulties in children with HI could be compared to normally hearing children. The unweighted average $g$ for these studies was 0.36 . The metaanalysis of the 12 SDQ studies gave estimated effect sizes of 0.23 (95\% CI 0.07, 0.40), 0.34 (95\% CI 0.19, 0.49) and -0.01 (95\% CI $-0.32,0.13$ ) for Parent, Teacher and Selfratings of Total Difficulties, respectively. The SDQ sub-scale showing consistent differences across raters between groups with $\mathrm{HI}$ and those with normal hearing was Peer Problems. Children and adolescents with $\mathrm{HI}$ have scores on emotional and behavioural difficulties measures about a quarter to a third of a standard deviation higher than hearing children. Children and adolescents with $\mathrm{HI}$ are in need of support to help their social relationships particularly with their peers.
\end{abstract}

\footnotetext{
J. Stevenson $(\bowtie) \cdot$ J. Kreppner

Faculty of Social and Human Sciences, University

of Southampton, Highfield, Southampton SO17 1BJ, UK

e-mail: jsteven@soton.ac.uk

H. Pimperton $\cdot$ S. Worsfold $\cdot$ C. Kennedy

Faculty of Medicine, University of Southampton, Southampton, $\mathrm{UK}$
}

Keywords Hearing impairment - Emotional difficulties · Behavioural difficulties

\section{Introduction}

The mental health of children with hearing impairment (HI) is of potential concern as their social-emotional development may be negatively impacted by difficulties in communication. Co-occurring cognitive and physical impairments are additional risk factors for many children with HI. These mental health risks may also be exacerbated by experiences within families and within the education system [1-3]. For this reason it is important to determine if, and to what extent, their mental health is less good than that of hearing children so that intervention could be targeted at this possibly vulnerable group. Studies on this question have largely adopted questionnaire measures of emotional and behavioural difficulties (EBD) and there is a wide variation between studies in the prevalence of EBD found in children with HI.

A range of mental health problems have been found to be associated with $\mathrm{HI}$ including depression, aggression, oppositional defiant disorder and conduct disorder, and less consistently anxiety, somatization, and delinquency [4]. There is an unresolved issue of whether children with HI show hyperactivity and inattention. It has been suggested that children with HI may be prone to show increased rates of hyperactivity and ADHD symptomatology [5], but this is not a consistent finding across studies. Kelly et al. [6] reported an association between HI and ADHD in acquired HI cases only. Van Eldik [7] found that it was only children with HI and low intelligence that showed attention problems. Finally, the association between HI and ADHD reported 
by Hindley and Kroll [5] was only significant for school-based hyperactivity, and there was no significant effect relative to the general population on parents' ratings of hyperactivity. Furthermore, some doubt was cast on the generalizability of this school-based finding by the suggestion that the effect may have arisen from the ratings of just one teacher [5].

In a narrative review of studies on EBD in children with HI, estimates varied between 0 and $77 \%$ in the rates of EBD [8]. There are a number of possible reasons for these discrepancies between studies, including differences in the sampling of children with HI (e.g. age, the extent of other associated impairments, and the nature and severity of hearing loss), differences in the measure used and in the informant on behaviour (i.e. parent, teacher or child). Meta-analysis provides a transparent and replicable method for synthesizing the results of such disparate studies, for discerning the overall mean effect and for identifying studies that do not conform to this general pattern, i.e. outliers [9].

To date there has been no attempt to give a quantitative assessment of the magnitude of differences in the rates of EBD in general, or on specific types of behaviour difficulties, in children with and without HI. This paper will present the results of two quantitative reviews that we have undertaken of studies on EBD in children with HI. One is of studies using a variety of measures of behaviour difficulties. The second is of studies using the Strength and Difficulties Questionnaire (SDQ) [10]. We have analysed separately those studies that did or did not use the SDQ because the non-SDQ studies have varied widely in the instrument used, which may or may not have included subscales. By contrast the SDQ studies, being all based on the same measure, are more homogeneous and provide well-validated sub-scale scores, with equivalent ratings based on parent, teacher and self-report which can be analysed separately but in parallel. The adoption of this measure in a number of recent investigations allows a more definitive appraisal of not only just the overall extent of EBD in children with HI but also of the type of difficulties shown and whether these are equally apparent to parents and to teachers. There are, in addition, a small number of studies using self-ratings on the SDQ by older children and adolescents.

The comparison of the results of these two separate analyses has to be made circumspectly. There are a wide variety of measures used in the non-SDQ review and pooling of results from disparate measures must be treated with caution. The majority of these non-SDQ measures are nevertheless widely adopted in studies of child behaviour and have been well validated.

\section{Method}

Studies not using SDQ

Non-SDQ study inclusion

These were studies of EBD in children and adolescents with HI which did not use the SDQ as a measure. For inclusion, the studies need to provide information from validated questionnaires or interviews on the prevalence of EBD or mean problem scores in children with HI. In addition, data from a control group or norm data from population samples should have been provided. If such comparison data were not provided, studies were still included if such norm data could be obtained subsequently from elsewhere.

\section{Non-SDQ study retrieval}

The following databases were searched for studies published between 1970 and June 2014: Science Citation Index Expanded (1970-present), Social Sciences Citation Index (1970-present), Arts \& Humanities Citation Index (1975present), Conference Proceedings Citation Index-Science (1990-present), Conference Proceedings Citation IndexSocial Science \& Humanities (1990-present), MEDLINE, PUBMED and PSYCHInfo. The search terms were (1) child* or adolescent* AND (2) deaf* or hearing or PCHI or cochlear implant* or hearing aid AND (3) behaviour problems or mental health.

To ensure maximum coverage of this disparate literature, citations in two authoritative earlier reviews $[8,11]$ and a recently published systematic review [4] were also checked.

Non-SDQ study selection

The search identified 48 papers that possibly could have been included but 15 of these studies did not meet the inclusion criteria. These papers and the reason for their exclusion are given in Table 1. From these various sources, there were therefore a total of 33 papers on non-SDQ EBD measures that met the inclusion criteria and details of these papers are given in Table 2. A summary of the selection of the non-SDQ studies is given in Fig. 1 in the form of a PRISMA flow chart [71].

Studies using SDQ

$S D Q$ study inclusion

To be included the studies had to provide summary statistics on either a continuous scale (means and SD) or 
Table 1 Non-SDQ studies identified in the systematic search but excluded from the meta-analysis

\begin{tabular}{|c|c|}
\hline Study & Reason for exclusion \\
\hline Aplin [12] & Data not able to be compared with hearing controls \\
\hline Aplin [13] & Data not able to be compared with hearing controls \\
\hline Barker et al. [14] & Data not able to be compared with hearing controls \\
\hline Bat-Chava and Deignan [15] & Data not able to be compared with hearing controls \\
\hline Bat-Chava, Martin and Kosciw [16] & Data not able to be compared with hearing controls \\
\hline Bizjak [17] & $\begin{array}{l}\text { Behaviour measured with instrument of uncertain equivalence to } \\
\text { those used in other studies }\end{array}$ \\
\hline Freeman, Malkin, and Hastings [18] & Data not able to be compared with hearing controls \\
\hline Gallaudet research institute [19] & Data not able to be compared with hearing controls \\
\hline Hindley et al. [6] & Data not able to be compared with hearing controls \\
\hline Keilman, Limberger, and Mann [20] & Data not able to be compared with hearing controls \\
\hline Kent [21] & $\begin{array}{l}\text { Behaviour measured with instrument of uncertain equivalence to } \\
\text { those used in other studies }\end{array}$ \\
\hline King, Mulhall, and Gullone [22] & $\begin{array}{l}\text { Behaviour measured with instrument of uncertain equivalence to } \\
\text { those used in other studies }\end{array}$ \\
\hline Kouwenberg et al. [23] & $\begin{array}{l}\text { Behaviour measured with instrument of uncertain equivalence to } \\
\text { those used in other studies }\end{array}$ \\
\hline Maes and Grietens [24] & Data not able to be compared with hearing controls \\
\hline Polat [25] & Data not able to be compared with hearing controls \\
\hline
\end{tabular}

in categorical form (percentage with abnormal scores) for children or adolescents with HI on any of the Parent, Teacher or Self-rated versions of the SDQ. Each of these three versions of the SDQ gives an overall Total Difficulties score and five sub-scale scores for Emotional Symptoms, Conduct Problems, Hyperactivity, Peer Problems and Prosocial Behaviour. A positive effect size indicates lower Prosocial scores for children with $\mathrm{HI}$ than hearing controls but higher scores for children with HI on the other SDQ sub-scales and Total Difficulties. These scores could be compared either with a normally hearing control group or with population norms. The search was limited to published papers to ensure a level of methodological adequacy and rigour amongst those included and to avoid the inevitable problems with securing access to a full set of unpublished studies and the bias that this would introduce [72].

\section{$S D Q$ study retrieval}

The following databases were searched for studies published between 1995 (when the SDQ was first published) and June 2014: Science Citation Index Expanded, Social Sciences Citation Index, Arts \& Humanities Citation Index, Conference Proceedings Citation Index-Science, Conference Proceedings Citation Index-Social Science \& Humanities, MEDLINE, PUBMED and PSYCHInfo. The search terms were (1) measure: SDQ or Strengths and Difficulties Questionnaire, AND (2) Participants: deaf* or Hearing or PCHI or Cochlear implant* or Hearing aid.

\section{$S D Q$ study selection}

The search identified 31 possible studies for inclusion. Of these 19 failed to meet the criteria above for study inclusion. The reasons for exclusion of these 19 studies are summarized in Table 3. The details of the 12 studies included in the analysis are presented in Table 4. The study selection was made independently by two of the authors (JS and HP). In the case of disagreements adjudication was made by a third author (CK). There were two studies where there was uncertainty over their inclusion. One was a study of children with Usher syndrome with complex disabilities in addition to hearing loss [73]. An additional issue with this paper was that SDQ scores were not reported for six children with diagnosed "mental or behavioural disorder". The second paper [74] studied children with $\mathrm{HI}$ associated with a persistent or recurrent history of middle ear disease. It was decided to include both these studies but to conduct a sensitivity analysis to determine if their exclusion modified the results materially. The data extraction was undertaken by JS and the accuracy of data extraction from the papers was determined by a second author (HP) independently checking the summary statistics used to derive the effect sizes for each study. A summary of the selection process for the SDQ studies is given in Fig. 2.

\section{Data for normally hearing comparison groups}

The studies may have no controls, their own control group or use a large general population sample for comparison 
Table 2 Characteristics of studies on EBD of children and adolescents with HI not using the SDQ

\begin{tabular}{|c|c|c|c|c|c|c|c|}
\hline & \multirow[t]{2}{*}{ Country } & \multirow{2}{*}{$\begin{array}{l}\text { Nature of HI } \\
\text { dB loss } \\
\% \text { Cochlear } \\
\text { implant (CI) }\end{array}$} & \multirow[t]{2}{*}{$\begin{array}{l}\text { Age in } \\
\text { years }\end{array}$} & \multirow[t]{2}{*}{ Measure } & \multicolumn{2}{|c|}{$\begin{array}{l}\% \text { With mental health problems or } \\
\text { Mean and SD on mental health measure }\end{array}$} & \multirow[t]{2}{*}{ Hedges' $g$} \\
\hline & & & & & $\begin{array}{l}\text { Hearing impaired } \\
\text { group }\end{array}$ & Control or norm group & \\
\hline \multirow{14}{*}{$\begin{array}{l}\text { Anderssen et al. } \\
\text { [26] }\end{array}$} & \multirow[t]{14}{*}{ Sweden } & \multirow{14}{*}{$\begin{array}{l}70 \% \text { severe or mild } \\
\text { hearing loss in } \\
\text { both ears } \\
30 \% \text { severe or mild } \\
\text { hearing loss in } \\
\text { one ear }\end{array}$} & \multirow[t]{14}{*}{$7-12$} & \multirow[t]{4}{*}{ Rutter Parent Scale } & & & \\
\hline & & & & & Mean $=1.95$ & Mean $=1.84$ & 0.16 \\
\hline & & & & & $\mathrm{SD}=0.88$ & $\mathrm{SD}=0.59$ & \\
\hline & & & & & $N=57$ & $N=187$ & \\
\hline & & & & \multirow[t]{3}{*}{ Externalizing } & Mean $=1.73$ & Mean $=1.59$ & 0.24 \\
\hline & & & & & $\mathrm{SD}=0.75$ & $\mathrm{SD}=0.52$ & \\
\hline & & & & & $N=57$ & $N=187$ & \\
\hline & & & & \multicolumn{4}{|l|}{ Rutter Teacher Scale ${ }^{b}$} \\
\hline & & & & \multirow[t]{3}{*}{ Internalizing } & Mean $=2.04$ & Mean $=1.81$ & 0.28 \\
\hline & & & & & $\mathrm{SD}=0.89$ & $\mathrm{SD}=0.80$ & \\
\hline & & & & & $N=48$ & $N=208$ & \\
\hline & & & & \multirow[t]{3}{*}{ Externalizing } & Mean $=1.41$ & Mean $=1.40$ & 0.01 \\
\hline & & & & & $\mathrm{SD}=0.63$ & $\mathrm{SD}=0.70$ & \\
\hline & & & & & $N=48$ & $N=208$ & \\
\hline \multirow[t]{2}{*}{$\begin{array}{l}\text { Arnold and Atkins } \\
\text { [27] }\end{array}$} & \multirow[t]{2}{*}{ England } & \multirow[t]{2}{*}{ Mean 66.7 dB loss } & \multirow[t]{2}{*}{$4-11$} & $\begin{array}{l}\text { Bristol Social Adjustment } \\
\text { Guide }^{\mathrm{a}}\end{array}$ & $44 \%(n=10 / 23)$ & $30 \%(n=7 / 23)$ & 0.30 \\
\hline & & & & Rutter Teacher Scale ${ }^{\mathrm{b}}$ & $0 \%$ & $0 \%$ & - \\
\hline \multirow{7}{*}{$\begin{array}{l}\text { Brubaker and } \\
\text { Szakowski [28] }\end{array}$} & USA & $8 \%$ & $3-18$ & Eyberg Child Behavior Inv & tory & & \\
\hline & & $\begin{array}{l}30-44 \mathrm{~dB} \\
13 \%\end{array}$ & & Intensity scale & Mean $=104.15$ & Mean $=91.43$ & 0.52 \\
\hline & & $45-59$ dB $18 \%$ & & & $\mathrm{SD}=25.86$ & $\mathrm{SD}=22.86$ & \\
\hline & & $60-79 \mathrm{~dB}$ & & & $N=39$ & $N=37$ & \\
\hline & & $80+\mathrm{dB}$ & & Problem scale & Mean $=8.05$ & Mean $=6.39$ & 0.27 \\
\hline & & & & & $\mathrm{SD}=6.54$ & $\mathrm{SD}=5.90$ & \\
\hline & & & & & $N=39$ & $N=37$ & \\
\hline Cornes et al. [29] & Australia & $15 \%$ severe & $11-18$ & Youth Self Report $^{\mathrm{n}}$ & & & \\
\hline & & & & Internalizing & $17.9 \%(n=5 / 28)$ & $19.6 \%(n=250 / 1273)$ & -0.06 \\
\hline & & & & Externalizing & $25.0 \%(n=7 / 21)$ & $16.4 \%(n=209 / 1273)$ & 0.29 \\
\hline Davis et al. [30] & USA & $40 \%<44 \mathrm{~dB}$ & $5-18$ & Child Behavior Checklist $^{\mathrm{c}}$ & & & \\
\hline & & $\begin{array}{l}37.5 \% 45-60 \mathrm{~dB} \\
22.5 \%>61 \mathrm{~dB}\end{array}$ & & Internalizing & Mean $=53.0$ & Mean $=50.0^{\mathrm{h}}$ & 0.30 \\
\hline & & & & & $\mathrm{SD}=10.1$ & $\mathrm{SD}=10$ & \\
\hline & & & & & $N=40$ & $N=300$ & \\
\hline & & & & Externalizing & Mean $=54.2$ & Mean $=50.0^{\mathrm{h}}$ & 0.42 \\
\hline & & & & & $\mathrm{SD}=10.4$ & $\mathrm{SD}=10$ & \\
\hline & & & & & $N=40$ & $N=300$ & \\
\hline Edwards et al. [31] & England & Profound pre-CI & $2-5$ & $\mathrm{CBCL}^{\mathrm{g}}$ & & & \\
\hline & & & & Internalizing & Mean $=50.5$ & Mean $=50.0^{\mathrm{h}}$ & 0.05 \\
\hline & & & & & $\mathrm{SD}=7.2$ & $\mathrm{SD}=10.0$ & \\
\hline & & & & & $N=17$ & $N=300$ & \\
\hline & & & & Externalizing & Mean $=51.2$ & Mean $=50.0^{\mathrm{h}}$ & 0.12 \\
\hline & & & & & $\mathrm{SD}=8.3$ & $\mathrm{SD}=10.0$ & \\
\hline & & & & & $N=17$ & $N=300$ & \\
\hline Fundudis et al. [32] & England & $\begin{array}{l}\text { Deaf not further } \\
\text { specified }\end{array}$ & $7-10$ & Rutter Teacher Scale ${ }^{\mathrm{b}}$ & $44 \%(n=24 / 54)^{\mathrm{b}}$ & $18 \%(n=18 / 102)^{\mathrm{i}}$ & 0.72 \\
\hline Furstenberg and & USA & $80 \%$ & $11-21$ & Teacher Report Form ${ }^{\mathrm{d}}$ & Average across grac & & \\
\hline Doyal [33] & & $\begin{array}{l}\text { Serious or profound } \\
\text { hearing loss in }\end{array}$ & & Internalizing & Mean $=53.71$ & Mean $=50.0^{\mathrm{j}}$ & 0.38 \\
\hline & & both ears & & & $\mathrm{SD}=8.73$ & $\mathrm{SD}=10$ & \\
\hline & & & & & $N=63$ & $N=300$ & \\
\hline & & & & Externalizing & Mean $=53.16$ & Mean $=50.0^{\mathrm{j}}$ & 0.33 \\
\hline & & & & & $\mathrm{SD}=6.95$ & $\mathrm{SD}=10$ & \\
\hline & & & & & $N=63$ & $N=300$ & \\
\hline
\end{tabular}


Table 2 continued

\begin{tabular}{|c|c|c|c|c|c|c|c|}
\hline & \multirow[t]{2}{*}{ Country } & \multirow{2}{*}{$\begin{array}{l}\text { Nature of HI } \\
\text { dB loss } \\
\% \text { Cochlear } \\
\text { implant }(\mathrm{CI})\end{array}$} & \multirow[t]{2}{*}{$\begin{array}{l}\text { Age in } \\
\text { years }\end{array}$} & \multirow[t]{2}{*}{ Measure } & \multicolumn{2}{|c|}{$\begin{array}{l}\% \text { With mental health problems or } \\
\text { Mean and SD on mental health measure }\end{array}$} & \multirow[t]{2}{*}{ Hedges' $g$} \\
\hline & & & & & $\begin{array}{l}\text { Hearing impaired } \\
\text { group }\end{array}$ & Control or norm group & \\
\hline \multirow{6}{*}{$\begin{array}{l}\text { Hindley and Kroll } \\
{[5]}\end{array}$} & \multirow[t]{6}{*}{ England } & \multirow[t]{6}{*}{$>40 \mathrm{~dB}$} & \multirow[t]{6}{*}{$11-16$} & \multirow{6}{*}{$\begin{array}{l}\text { Rutter Parent Scale } \\
\text { Rutter Teacher Scale }^{\mathrm{e}}\end{array}$} & Hyperactive home & Hyperactive home & \multirow[t]{2}{*}{-0.15} \\
\hline & & & & & $9.9 \%(n=8 / 81)$ & $12.7 \%(n=63 / 498)$ & \\
\hline & & & & & $\begin{array}{l}\text { Hyperactive } \\
\text { school }\end{array}$ & Hyperactive school & \multirow[t]{2}{*}{0.48} \\
\hline & & & & & $\begin{array}{l}16.0 \% \\
\quad(n=13 / 81)\end{array}$ & $7.2 \%(n=36 / 498)$ & \\
\hline & & & & & $\begin{array}{l}\text { Hyperactive } \\
\text { pervasive }\end{array}$ & Hyperactive pervasive & \multirow[t]{2}{*}{0.37} \\
\hline & & & & & $8.6 \%(n=7 / 81)$ & $4.6 \%(n=23 / 498)$ & \\
\hline Kammerer [34] & Germany & $>20 \mathrm{~dB}$ & $10-13$ & Rutter Teacher Scale ${ }^{\mathrm{b}}$ & $\begin{array}{l}54 \% \\
\quad(n=99 / 183)^{\mathrm{b}}\end{array}$ & $16 \%^{\mathrm{i}}$ & 1.00 \\
\hline \multirow[t]{16}{*}{ Kelly et al. [6] } & \multirow[t]{16}{*}{ USA } & \multirow{16}{*}{$\begin{array}{l}89 \% \\
\text { Severe or greater } \\
\text { loss }\end{array}$} & \multirow[t]{16}{*}{$4-21$} & \multirow{4}{*}{$\begin{array}{l}\text { Conners' Parent Rating Scale } \\
\text { Impulsive-hyperactive }\end{array}$} & Females & Females & \\
\hline & & & & & Mean $=0.77$ & Mean $=0.83$ & -0.09 \\
\hline & & & & & $\mathrm{SD}=0.72$ & $\mathrm{SD}=0.61$ & \\
\hline & & & & & $N=97$ & $N=238$ & \\
\hline & & & & \multirow[t]{4}{*}{ Impulsive-hyperactive } & Males & Males & \\
\hline & & & & & Mean $=0.66$ & Mean $=0.89$ & -0.39 \\
\hline & & & & & $\mathrm{SD}=0.65$ & $\mathrm{SD}=0.59$ & \\
\hline & & & & & $N=115$ & $N=291$ & \\
\hline & & & & \multirow[t]{4}{*}{ Hyperactivity } & Females & Females & \\
\hline & & & & & Mean $=0.52$ & Mean $=0.55$ & -0.07 \\
\hline & & & & & $\mathrm{SD}=0.55$ & $\mathrm{SD}=0.39$ & \\
\hline & & & & & $N=97$ & $N=238$ & \\
\hline & & & & Hyperactivity & Males & Males & \\
\hline & & & & & Mean $=0.52$ & Mean $=0.65$ & -0.29 \\
\hline & & & & & $\mathrm{SD}=0.49$ & $\mathrm{SD}=0.44$ & \\
\hline & & & & & $N=115$ & $N=291$ & \\
\hline Konuk et al. [35] & Turkey & $3 \% 56-70 \mathrm{db}$ & $6-18$ & Child Behavior Checklist $^{\mathrm{c}}$ & & & \\
\hline & & $\begin{array}{l}8 \% 71-90 \mathrm{db} \\
89 \%>91 \mathrm{db}\end{array}$ & & Internalizing & Mean $=57.84$ & Mean $=52.11$ & 0.50 \\
\hline & & & & & $\mathrm{SD}=11.78$ & $\mathrm{SD}=10.74$ & \\
\hline & & & & & $N=72$ & $N=45$ & \\
\hline & & & & Externalizing & Mean $=51.98$ & Mean $=50.11$ & 0.15 \\
\hline & & & & & $\mathrm{SD}=12.02$ & $\mathrm{SD}=12.24$ & \\
\hline & & & & & $N=72$ & $N=45$ & \\
\hline Kouwenberg et al. & The Netherlands & $>40 \mathrm{~dB}$ & $8-15$ & Child Depression Inventory $^{0}$ & Mean $=1.39$ & Mean $=1.33$ & 0.29 \\
\hline & & $37 \% \mathrm{CI}$ & & & $\mathrm{SD}=0.21$ & $\mathrm{SD}=0.20$ & \\
\hline & & & & & $N=78$ & $N=130$ & \\
\hline Li and Prevatt [37] & China & Deaf not further & $8-19$ & Revised Children's Manifest & Females & Females & \\
\hline & & specified & & Anxiety Scale ${ }^{\mathrm{s}}$ & Mean $=14.30$ & Mean $=10.61$ & 0.71 \\
\hline & & & & & $\mathrm{SD}=5.10$ & $\mathrm{SD}=5.08$ & \\
\hline & & & & & $N=30$ & $N=34$ & \\
\hline & & & & & Males & Males & \\
\hline & & & & & Mean $=15.55$ & Mean $=11.18$ & 1.08 \\
\hline & & & & & $\mathrm{SD}=3.36$ & $\mathrm{SD}=4.50$ & \\
\hline & & & & & $N=31$ & $N=30$ & \\
\hline Mitchell and & USA & $53 \%$ & $6-14$ & Child Behavior Checklist $^{c}$ & Mean $=58.0$ & Mean $=50.0^{\mathrm{h}}$ & 0.79 \\
\hline Quittner [38] & & $\begin{array}{l}70-100 \mathrm{~dB} \\
47 \%>100 \mathrm{~dB}\end{array}$ & & & $\mathrm{SD}=10.5$ & $\mathrm{SD}=10.0$ & \\
\hline & & & & & $N=39$ & $N=300$ & \\
\hline & & & & Teacher Report Form ${ }^{\mathrm{d}}$ & Mean $=56.8$ & Mean $=50.0^{\mathrm{j}}$ & 0.71 \\
\hline & & & & & $\mathrm{SD}=5.2$ & $\mathrm{SD}=10.0$ & \\
\hline & & & & & $N=39$ & $N=300$ & \\
\hline
\end{tabular}


Table 2 continued

\begin{tabular}{|c|c|c|c|c|c|c|c|}
\hline & \multirow[t]{2}{*}{ Country } & \multirow{2}{*}{$\begin{array}{l}\text { Nature of HI } \\
\text { dB loss } \\
\% \text { Cochlear } \\
\text { implant (CI) }\end{array}$} & \multirow[t]{2}{*}{$\begin{array}{l}\text { Age in } \\
\text { years }\end{array}$} & \multirow[t]{2}{*}{ Measure } & \multicolumn{2}{|c|}{$\begin{array}{l}\% \text { With mental health problems or } \\
\text { Mean and SD on mental health measure }\end{array}$} & \multirow[t]{2}{*}{ Hedges' $g$} \\
\hline & & & & & $\begin{array}{l}\text { Hearing impaired } \\
\text { group }\end{array}$ & Control or norm group & \\
\hline \multirow[t]{2}{*}{ Prior et al. [39] } & \multirow[t]{2}{*}{ Australia } & \multirow{2}{*}{$\begin{array}{l}\text { All aided } \\
30-110 \mathrm{~dB}\end{array}$} & \multirow[t]{2}{*}{$2-5$} & Teacher rating PBQ & \multirow{2}{*}{\multicolumn{2}{|c|}{$t=3.72, \mathrm{df}=50$}} & \\
\hline & & & & Total score & & & $1.05^{\mathrm{q}}$ \\
\hline \multirow[t]{4}{*}{ Quittner et al. [40] } & \multirow[t]{4}{*}{ USA } & \multirow[t]{4}{*}{ Severe to profound } & \multirow[t]{4}{*}{ Under 5} & $\mathrm{CBCL}^{\mathrm{n}}$ & & & \\
\hline & & & & Total score & Mean $=24.81$ & Mean $=18.73$ & 0.27 \\
\hline & & & & Based on full information & $\mathrm{SD}=21.52$ & $\mathrm{SD}=14.29$ & \\
\hline & & & & & $N=181$ & $N=92$ & \\
\hline \multirow{6}{*}{$\begin{array}{l}\text { Remine and Brown } \\
\text { [41] }\end{array}$} & \multirow[t]{6}{*}{ Australia } & \multirow{6}{*}{$\begin{array}{l}\text { Deaf not further } \\
\text { specified }\end{array}$} & \multirow[t]{6}{*}{$6-18$} & Child Behavior Checklist $^{\mathrm{c}}$ & & & \\
\hline & & & & Internalizing & $16.9 \%(11 / 65)$ & $13.3 \%(433 / 3255)$ & 0.16 \\
\hline & & & & Externalizing & $13.8 \%(9 / 65)$ & $12.7 \%(413 / 3255)$ & 0.06 \\
\hline & & & & Youth Self-Report $^{\mathrm{n}}$ & & & \\
\hline & & & & Internalizing & $11.4 \%(4 / 35)$ & $16.4 \%(209 / 1273)$ & -0.23 \\
\hline & & & & Externalizing & $8.6 \%(3 / 35)$ & $19.6 \%(249 / 1273)$ & -0.53 \\
\hline $\begin{array}{l}\text { Rutter, Graham, } \\
\text { and Yule [42] }\end{array}$ & England & At least $40 \mathrm{~dB}$ loss & $5-14$ & $\begin{array}{l}\text { Interview and question- } \\
\text { naires }\end{array}$ & $15 \%(n=2 / 13)^{\mathrm{b}}$ & $7 \%(n=153 / 2189)^{\mathrm{i}}$ & 0.49 \\
\hline \multirow{4}{*}{$\begin{array}{l}\text { Sahli, Arslan, and } \\
\text { Belgin [43] }\end{array}$} & \multirow[t]{4}{*}{ Turkey } & $100 \%$ with CI & $6-18$ & Rosenberg Self-Esteem Scale & & & \\
\hline & & & & Depressive emotioning & Mean $=3.02$ & Mean $=2.30$ & 0.67 \\
\hline & & & & & $\mathrm{SD}=1.68$ & $\mathrm{SD}=0.53$ & \\
\hline & & & & & $N=30$ & $N=60$ & \\
\hline Sinkkonen [44] & Finland & $\begin{array}{l}\text { Deaf not further } \\
\text { specified }\end{array}$ & $6-16$ & Rutter Teacher Scale ${ }^{\mathrm{b}}$ & $\begin{array}{l}21 \% \\
\quad(n=62 / 294)^{\mathrm{b}}\end{array}$ & $16 \%(n=37 / 234)^{\mathrm{i}}$ & 0.19 \\
\hline Tharpe et al. [45] & USA & At least $80 \mathrm{~dB}$ loss & $8-14$ & Child Behavior Checklist $^{\mathrm{c}}$ & Mean $=47.07^{\mathrm{k}}$ & Mean $=37.20$ & 1.11 \\
\hline & & & & & $\mathrm{SD}=6.80$ & $\mathrm{SD}=11.25$ & \\
\hline & & & & & $N=18$ & $N=10$ & \\
\hline & & & & Teacher Report Form $^{\mathrm{d}}$ & Mean $=46.48^{\mathrm{k}}$ & Mean $=46.00$ & 0.05 \\
\hline & & & & & $\mathrm{SD}=7.56$ & $\mathrm{SD}=11.25$ & \\
\hline & & & & & $N=17$ & $N=8$ & \\
\hline Theunissen et al. & The Netherlands & $24 \% 40-60 \mathrm{~dB}$ loss & $8-16$ & Child Depression Inventory ${ }^{\circ}$ & Mean $=1.38$ & Mean $=1.32$ & 0.30 \\
\hline & & $\begin{array}{l}28 \% 61-90 \mathrm{~dB} \text { loss } \\
34 \%>90 \mathrm{~dB} \text { loss }\end{array}$ & & & $\mathrm{SD}=0.21$ & $\mathrm{SD}=0.19$ & \\
\hline & & $14 \%$ & & & $N=83$ & $N=117$ & \\
\hline & & $\begin{array}{l}\text { Not known } \\
33 \% \text { CI }\end{array}$ & & & & & \\
\hline Theunissen et al. & The Netherlands & $26 \% 40-60 \mathrm{~dB}$ loss & $9-16$ & Child symptom inventories $^{\mathrm{p}}$ & & & \\
\hline$[47]$ & & $\begin{array}{l}21 \% 61-90 \mathrm{~dB} \text { loss } \\
53 \%>90 \mathrm{~dB} \text { loss }\end{array}$ & & Generalized anxiety & Mean $=1.50$ & Mean $=1.36$ & 0.35 \\
\hline & & $14 \%$ & & disorder & $\mathrm{SD}=0.46$ & $\mathrm{SD}=0.35$ & \\
\hline & & Not known & & & $N=72$ & $N=98$ & \\
\hline Theunissen et al. & The Netherlands & $24 \% 40-60 \mathrm{~dB}$ loss & $8-16$ & Child symptom inventories ${ }^{p}$ & & & \\
\hline$[48]$ & & $\begin{array}{l}21 \% 61-90 \mathrm{~dB} \text { loss } \\
49 \%>90 \mathrm{~dB} \text { loss }\end{array}$ & & ADHD & $t=2.84 \mathrm{df}=192$ & & $0.41^{\mathrm{q}}$ \\
\hline & & $7 \%$ & & ODD & $t=2.65 \mathrm{df}=192$ & & $0.38^{\mathrm{q}}$ \\
\hline & & Not known & & $\mathrm{CD}$ & $t=3.30 \mathrm{df}=192$ & & $0.48^{\mathrm{q}}$ \\
\hline Topol et al. [49] & USA & $40 \%$ & $1.5-2$ & Child Behavior Checklist & Mean $=45.9$ & Mean $=43.5$ & 0.26 \\
\hline & & $\begin{array}{l}\text { Unilateral } \\
\text { or }<40 \mathrm{~dB}\end{array}$ & & $1.5-5^{1}$ & $\mathrm{SD}=5.2$ & $\mathrm{SD}=10.3$ & \\
\hline & & loss & & & $N=30$ & $N=91$ & \\
\hline Van Eldik [50] & The Netherlands & $+80 \mathrm{~dB}$ & $6-11$ & $\mathrm{CBCL}^{\mathrm{c}}$ & & & \\
\hline & & & & Total score & $t=2.10, \mathrm{df}=493$ & & $0.19^{\mathrm{q}}$ \\
\hline Van Eldik et al. [7] & The Netherlands & $>90 \mathrm{~dB}$ & $4-18$ & Child Behavior Checklist $^{\mathrm{c}}$ & $41 \%(n=98 / 238)$ & $16 \%(n=331 / 2068)$ & 0.72 \\
\hline Van Eldik [51] & The Netherlands & $>25 \mathrm{~dB}$ & $11-18$ & Youth Self Report ${ }^{\mathrm{g}}$ & $37 \%(n=75 / 202)$ & $17 \%(n=173 / 1016)$ & 0.58 \\
\hline Van Gent et al. [8] & The Netherlands & $19 \% 73-95 \mathrm{~dB}$ & $13-21$ & Child Behavior Checklist $^{\mathrm{c}}$ & $28 \%(n=16 / 58)$ & $16 \%$ & 0.38 \\
\hline & & $81 \%>95 \mathrm{~dB}$ & & Teacher Report Form ${ }^{\mathrm{d}}$ & $32 \%(n=22 / 68)$ & $17 \%$ & 0.47 \\
\hline Vostanis et al. [2] & England & Severe to profound & $2-18$ & Child Behavior Checklist $^{\mathrm{c}}$ & $40 \%(n=29 / 73)$ & $8 \%^{\mathrm{m}}$ & 1.11 \\
\hline
\end{tabular}


Table 2 continued

\begin{tabular}{|c|c|c|c|c|c|c|c|}
\hline & \multirow[t]{2}{*}{ Country } & \multirow{2}{*}{$\begin{array}{l}\text { Nature of HI } \\
\text { dB loss } \\
\% \text { Cochlear } \\
\text { implant }(\mathrm{CI})\end{array}$} & \multirow[t]{2}{*}{$\begin{array}{l}\text { Age in } \\
\text { years }\end{array}$} & \multirow[t]{2}{*}{ Measure } & \multicolumn{2}{|c|}{$\begin{array}{l}\% \text { With mental health problems or } \\
\text { Mean and SD on mental health measure }\end{array}$} & \multirow[t]{2}{*}{ Hedges' $g$} \\
\hline & & & & & $\begin{array}{l}\text { Hearing impaired } \\
\text { group }\end{array}$ & Control or norm group & \\
\hline Wake et al. [52] & Australia & $\begin{array}{l}22 \% \\
20-40 \mathrm{~dB} \\
31 \% \\
41-60 \mathrm{~dB} \\
17 \% 61-80 \mathrm{~dB} \\
29 \%>80 \mathrm{~dB}\end{array}$ & $7-8$ & $\begin{array}{l}\text { Child Behavior Checklist } \\
\text { Teacher Report Form }^{\mathrm{d}}\end{array}$ & $\begin{array}{l}36 \%(n=36 / 77) \\
20 \%(n=16 / 80)\end{array}$ & $\begin{array}{l}12 \%(n=24 / 198) \\
8 \%(n=7 / 86)\end{array}$ & $\begin{array}{l}1.02 \\
0.58\end{array}$ \\
\hline Watt and Davis [53] & USA & $>90 \mathrm{~dB}$ loss & $\begin{array}{c}\text { Mean age } \\
=13.7 \\
\text { years }\end{array}$ & Beck Depression Inventory ${ }^{r}$ & $\begin{array}{l}\text { Mean }=10.52 \\
\mathrm{SD}=5.59 \\
N=50\end{array}$ & $\begin{array}{l}\text { Mean }=6.62 \\
\mathrm{SD}=6.13 \\
N=30\end{array}$ & 0.66 \\
\hline
\end{tabular}

${ }^{\text {a }}$ Stott [54]

b Rutter [55]

c Achenbach and Edelbrock [56]

d Achenbach and Edelbrock [57]

e Rutter, Tizard and Whitmore [58]

${ }^{f}$ Goyette, Conners and Ulrich [59]

g Achenbach [60]

h Based on original standardization of CBCL

i Taken from van Gent et al. [8]

${ }^{j}$ Based on original standardization of TRF

${ }^{\mathrm{k}}$ Average of cochlear implant and hearing aid groups

${ }^{1}$ Achenbach [61]

${ }^{\mathrm{m}}$ Estimated from normal curve distribution percentage with $\mathrm{T}$ score greater than 64

${ }^{n}$ Achenbach and Rescorla [62]

o Kovacs [63]

p Gadow and Sprakin [64]

q $d=\frac{2 t}{\sqrt{\mathrm{df}}}$

r Beck et al. [65]

s Reynolds and Richmond [66]

t Rosenberg [67]

u Eyberg and Ross [68]

$\checkmark$ Behar and Springfield [69]

${ }^{w}$ Sawyer et al. [70]

purposes. There is a range of such general population samples that can provide norms for the SDQ. Different studies use different samples for normative comparisons. The use of these general population samples for comparison creates a severe distortion to the standard error of the Hedges' $g$ estimate. The sample sizes are of the order of 100 times the size of that for the studies using control groups. The random effects meta-analysis consequently gives these studies a much greater weight than those using their own controls. To overcome this distortion and to allow the inclusion of studies presenting no comparison data, the effect sizes for the impact of HI on SDQ scores were calculated using a common population sample to provide comparison data for all the studies. The norms provided by Meltzer et al. [94] were selected as these were based on a large British general population sample with norms available for parents $(N=10,298)$ and teachers $(N=8208)$ and for self-ratings for older children $(N=4228)$. For this sample norms are provided for two age ranges (5-10 years and 11-15 years). This therefore allows a limited adjustment for age effects to be achieved. For each study, the mean and SD for the age group norms closest in age to the hearing impaired sample was used for comparison. For those studies reporting only the percentage extreme scorers in the hearing impaired group, the appropriate percentage in the age-matched normative sample was used. These comparisons between children with $\mathrm{HI}$ and the general population sample could be made for Parent, Teacher and Self-ratings on the Total Difficulties score, for each of four problem sub-scales and for the Prosocial sub-scale. 
Fig. 1 PRISMA flow chart of selection of non-SDQ studies
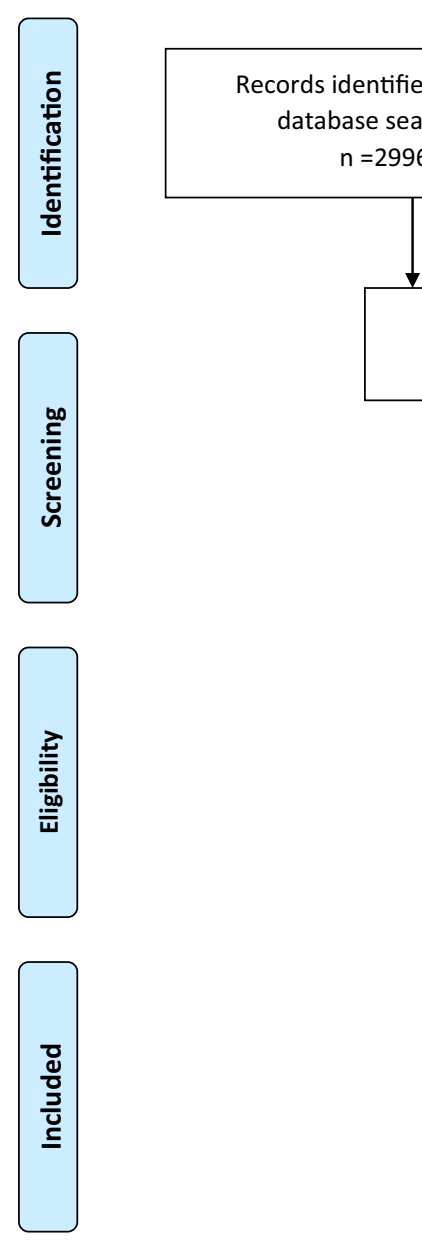

Additional records identified through other sources i.e. cites in Moeller [10], Theunissen et al. [11] and van Gent et al. [7]

\section{Calculating effect sizes}

For both SDQ and non-SDQ studies, the effect size used was Hedges' $g$ which provides a standardized mean difference in scores between children with HI and those with normal hearing as follows:

Hedges' $g=\frac{\text { Mean }_{\mathrm{HI}}-\text { Mean }_{\text {Controls }}}{\text { SD }_{\text {Pooled }}}\left[1-\frac{3}{4 N-9}\right]$

where $N=N_{\mathrm{HI}}+N_{\text {Controls }}$ and

$\mathrm{SD}_{\text {Pooled }}=\sqrt{\frac{\left(N_{\mathrm{HI}}-1\right) \mathrm{SD}_{\mathrm{HI}}^{2}+\left(N_{\text {Controls }}-1\right) \mathrm{SD}_{\text {Controls }}^{2}}{N-2}}$.

For studies using a categorical scoring, the log odds ratio was calculated and converted to $d$ and then to $g$ using the methods on p. 47 and p. 2 [9]. In all cases, a positive effect size indicates a higher EBD score for children with HI compared to normally hearing children.

The 32 studies not using the SDQ applied a range of methods of measuring behaviour in children with HI (see
Table 2). In addition, these studies used various sources for data on the mental health of normally hearing children, i.e. study-specific control groups and population norms. A meta-analysis usually involves averaging the Hedges' $g$ using a weighting procedure that reflects the confidence in the value of $g$-studies with a smaller standard error, usually associated with larger $N$, get greater weight. We did not do this for non-SDQ studies because of concerns over the heterogeneity in the range of measures used in the studies, the variation in control and norm groups used as comparators and because the effect size was based on means in some cases and percentage of extreme scorers in others. Instead the unweighted average value of Hedges' $g$ is reported (see [110] for a discussion of this approach). In addition to the average effect size for overall behaviour difficulties for these non-SDQ studies, the average effect sizes for internalizing and externalizing behaviours are also presented. The parent-rated child behavior checklist (CBCL) [56] total problem scores were the non-SDQ measure most frequently reported and an average effect size was calculated for these studies also. 
In the case of SDQ studies, the above considerations were not relevant and weighted Hedges' $g$ was used to provide a standardized mean difference between children with and without $\mathrm{HI}$ for each study. These values were used to undertake a meta-analysis using the metan command in Stata [111]. The estimate of the overall effect size was obtained using a random effects model, as the effect sizes in these studies were thought unlikely to be functionally equivalent given that different samples were being studied by different research groups in different countries. For the SDQ studies, a test was made to examine whether the magnitude of differences in behaviour between children with $\mathrm{HI}$ and controls changed with age. Meta-regressions were conducted using the metareg command in Stata [112] with Hedges' $g$ as the dependent and age the independent variable.

To provide "a like for like" comparison between SDQ and non-SDQ studies, we also report the unweighted Hedges' $g$ for SDQ studies.

\section{Results}

\section{Studies not using SDQ}

The 33 non-SDQ studies provided 57 estimates for the standardized mean difference $(g)$ of EBD scores for children with $\mathrm{HI}$ and hearing controls or a norm group (see Table 2). The unweighted mean effect size was 0.36 (95 \% CI 0.26, 0.46; range -0.53 to 1.11 ). There were 31 estimates based on Parent reports of behaviour with a mean value of 0.34 (95\%CI $0.21,0.47$; range -0.39 to 1.11 ). The 17 Teacher rating-based estimates gave a higher mean value of 0.46 (95\% CI 0.28 , 0.64 ; range 0.01 to 1.05 ). These estimates were a mix of effect sizes derived from continuous and categorical measures of EBD. The mean effect size for the 21 categorical measures was slightly higher $(0.38,95 \%$ CI $0.21,0.54$; range -0.39 to 1.11) than that for the 36 continuous indicators $(0.35,95 \%$ CI $0.23,0.47$; range -0.39 to 1.11 ). When estimates for internalizing and externalizing symptoms were available, a higher mean value of $\mathrm{g}$ was obtained for internalizing symptoms $(0.35,95 \%$ CI $0.19,0.51$; range -0.23 to 1.08$)$ than for externalizing behaviours $(0.12,95 \% \mathrm{CI}-0.03,0.26$; range -0.53 to 0.48 ). The highest effect size was obtained for total behaviour scores $(0.58,95 \%$ CI $0.44,0.72$; range 0.05 to 1.11). Of these effect sizes for total behaviour problems five were obtained from continuous scores on the CBCL rated by parents and provided an effect size of 0.52 (95\% CI 0.13 , 0.92). There are four studies in Table 2 that were not published in peer-reviewed journals. When these were excluded the unweighted mean effect size was reduced slightly to 0.34 (95\% CI 0.24, 0.45; range -0.53 to 1.11 ).

\section{Studies using SDQ}

There were 12 SDQ studies which provided 10 Parent, 9 Teacher and 4 Self-rated estimates of effect size for

Table 3 SDQ studies identified in the systematic search but excluded from the meta-analysis

\begin{tabular}{|c|c|}
\hline Study & Reason for exclusion \\
\hline Fellinger et al. [75] & Sub-set of participants reported in Fellinger et al. [99] \\
\hline Fellinger et al. [76] & Same participants as in Fellinger et al. [99] \\
\hline Fellinger and Holzinger [77] & Not peer reviewed \\
\hline Garg et al. [78] & $\begin{array}{l}\text { No report of findings by hearing loss, although neurofibromatosis } \\
\text { type } 2 \text { is associated with hearing loss }\end{array}$ \\
\hline Gurney et al. [79] & Did not use the SDQ \\
\hline Hintermair [80] & Duplicate of data in Hintermair [101] \\
\hline Hintermair [81] & Did not provide means and SDs \\
\hline Hutchison and Gordon [82] & Not only children with HI \\
\hline Ketelaar et al. [83] & Non-standard use of sub-set of SDQ items \\
\hline Marret et al. [84] & Not only children with HI \\
\hline McCormack et al. [85] & Not only children with HI \\
\hline Moller [86] & Adults with complex disabilities \\
\hline Muigg, Nekahm-Heis, and Juen [87] & Did not provide means and SDs \\
\hline Rieffe, Ketelaar, and Wiefferink [88] & Not on children with HI \\
\hline Saigal et al. [89] & Not just children with HI \\
\hline St Clair et al. [90] & Not just children with HI \\
\hline Stevenson et al. [1] & Same sample as Stevenson et al. [107] \\
\hline Sumpter et al. [91] & Not just children with HI \\
\hline Watson and Brown [92] & No new data—editorial \\
\hline
\end{tabular}




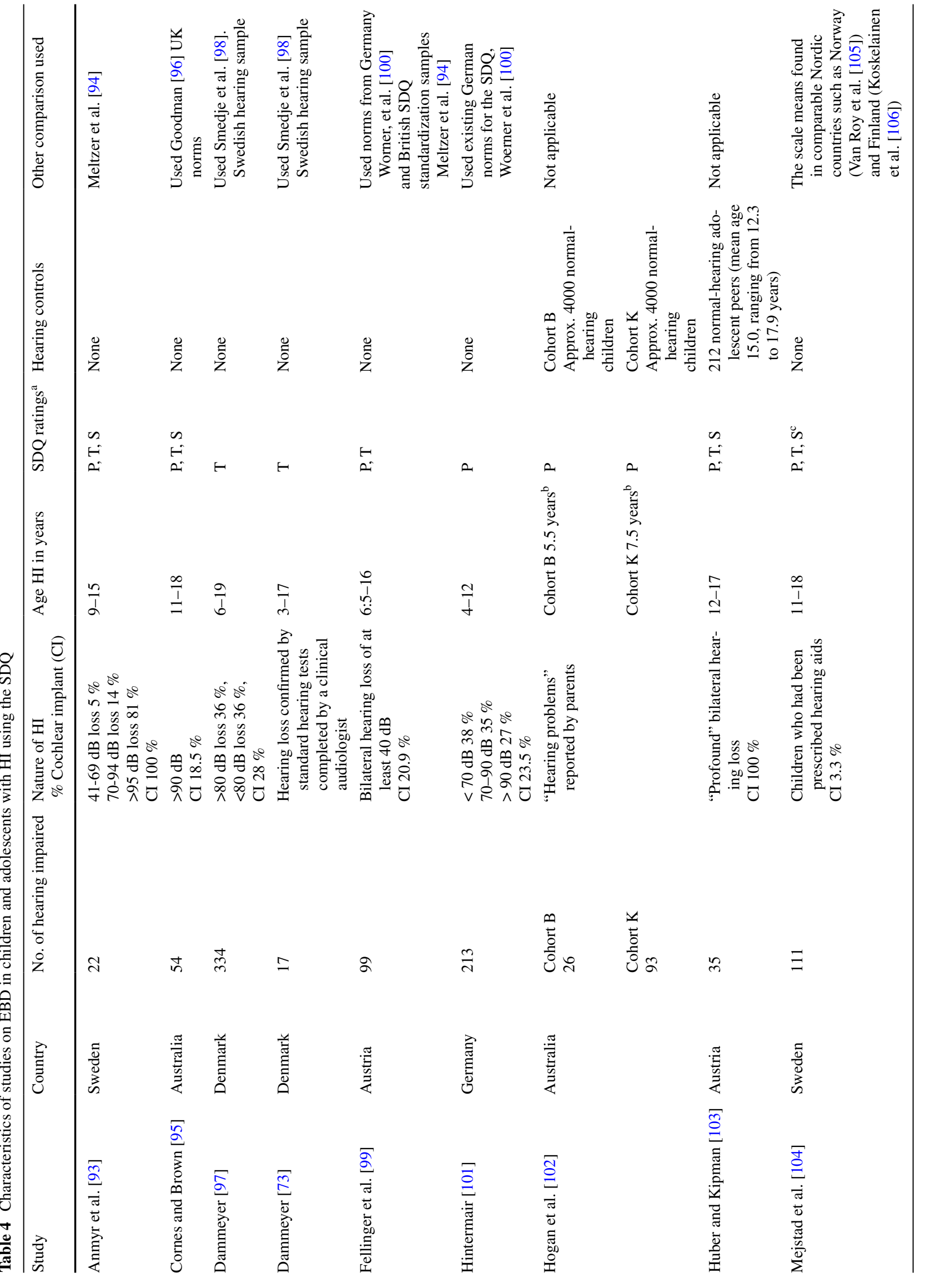




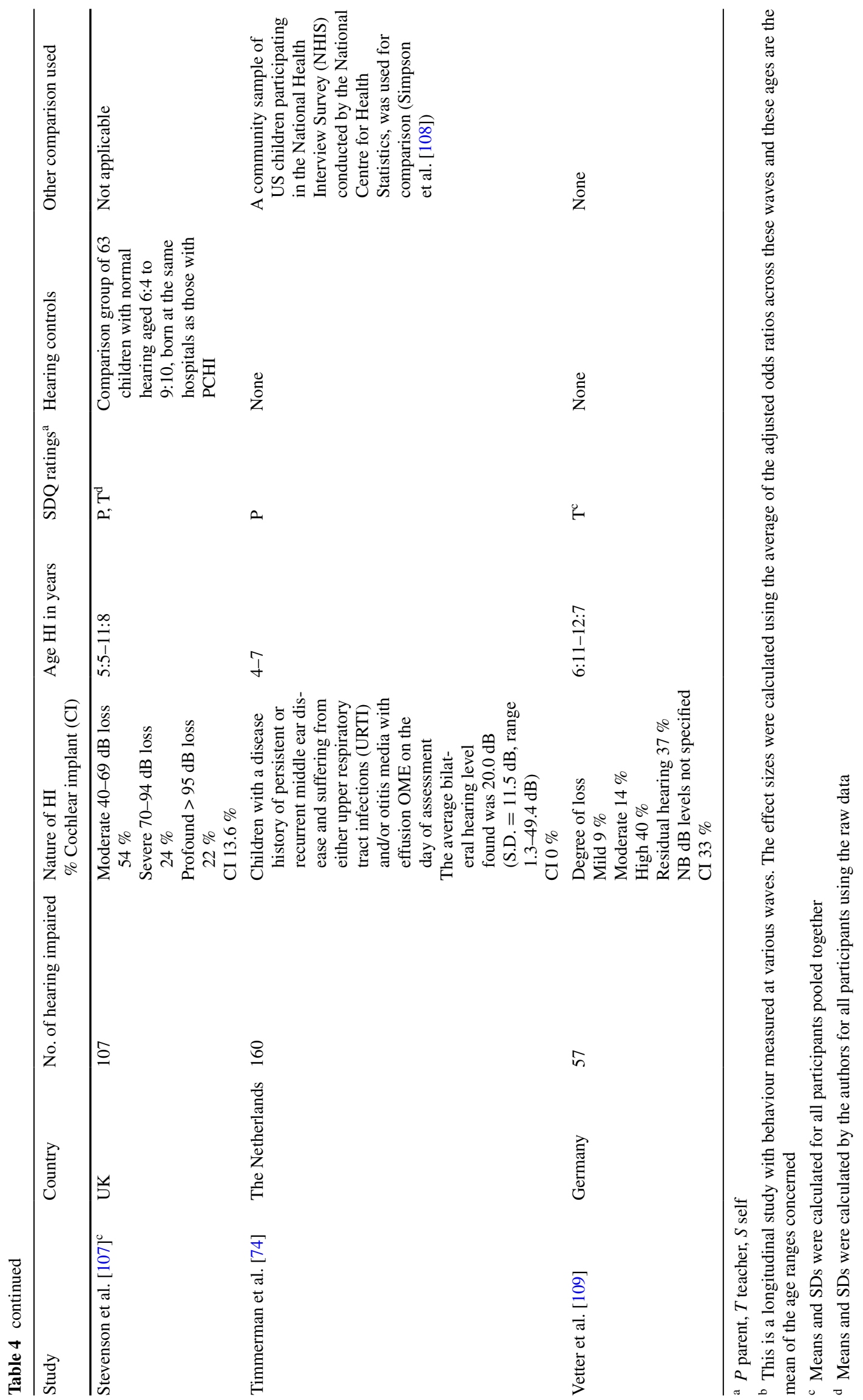


Fig. 2 PRISMA flow chart of selection of SDQ studies

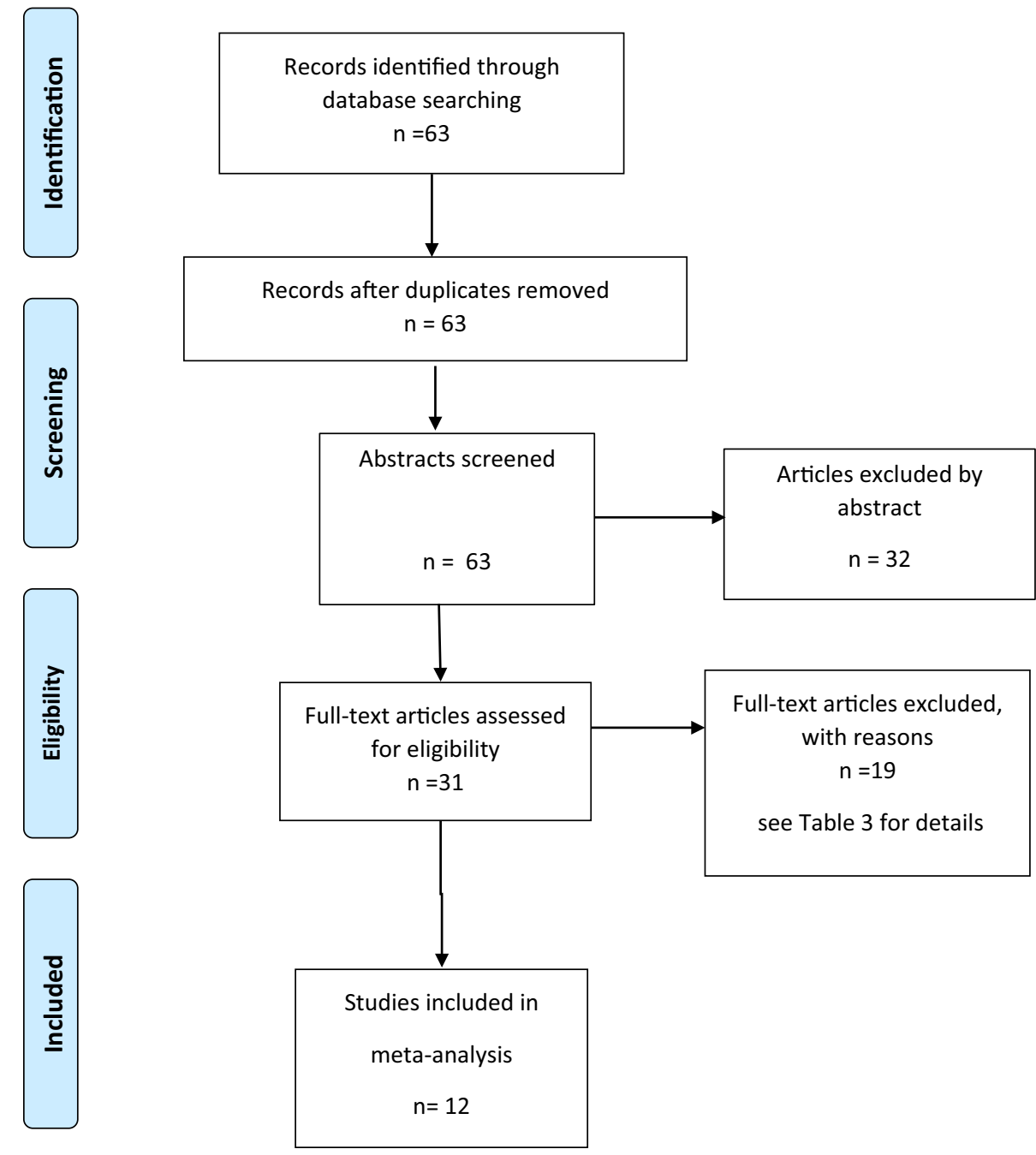

Total Difficulties. There were 10, 6 and 4 estimates available for the SDQ sub-scales for Parents, Teacher and Selfrated scores, respectively. One study provided data on two cohorts each of which had SDQ assessment by parents on multiple occasions [102]. The average percentage of high scorers across the assessment's multiple pre-specified time points was entered into the meta-analysis separately for each cohort.

The random effects model estimates of effect size are presented in Table 5. There is a significant effect size for Parent (0.23) and Teacher (0.34) ratings of Total Difficulties but not for Self-rated scores $(-0.01)$, respectively. The heterogeneity indices based on $\chi^{2}$ are significant for Parent and Teacher ratings. The high values of $I^{2}$ suggest that there are systematic rather than random differences between the estimates from the studies. A larger set of studies would be needed to explore the reason for this heterogeneity using meta-regression.

The results for Self-rated estimates have to be treated cautiously as these are based on just four studies. There is a pattern whereby the children and adolescents rate themselves as having fewer difficulties than those reported by Parents and Teachers. The exception is Peer Problems where the Self-rated score gives the highest effect size of all (0.41).

Forest plots of the effect sizes for Parent and for Teacher Total Difficulties scores are presented in Fig. 3A and B. There are too few studies with self-rated scores to warrant presentation. A somewhat surprising finding is that of Anmyr et al. [93] which is the only study to produce a significant effect size that shows children with HI have lower Total Difficulties score than hearing controls, but this is found for Parent ratings only.

Only the SDQ Peer Problem sub-scale shows a consistent pattern of more difficulties for children with HI. The estimate is significant for Parent, Teacher and Selfrated scores (effect size of $0.27,0.35$ and 0.41 , respectively). The effect sizes for Parent and Teacher scores for Peer Problems for individual studies are shown in Fig. 3C and D. 
Meta-regression for age

To test whether the effect size changed with age, metaregressions were conducted for all scales for all raters. In 14 of these 18 regressions the effect size declined with age but only in the case of Self-ratings on the Emotional Symptoms scale did this reach significance (coefficient $=-0.14$, $\mathrm{SE}=0.02, P<0.02)$.

\section{Sensitivity analyses}

The effect sizes presented above are based on both categorical and continuous measures of EBD. A sensitivity analysis was carried out on Parent and Teacher ratings to establish whether restricting the meta-analysis to continuous-only measures changed the pattern of results. This was not possible for Self-rated measures as there were too few values. The effect sizes based on continuous measures alone are presented in Table 5. The pattern of results remains largely unchanged.

The effect of removing the two studies where inclusion was uncertain was that the effect size for Parent Total Difficulties was little changed (0.25) and for Teacher Total Difficulties fell from 0.34 to 0.31 and in both cases the effect remained significant.

\section{Comparing the non-SDQ and SDQ study effect sizes}

The methods of summarizing effect sizes described so far for the SDQ studies are different from those reported above for the non-SDQ studies. To allow a more appropriate comparison to be made, Table 5 includes in the final column a value for the unweighted mean effect size; the same summary as was given for the non-SDQ studies in Table 2. As reported above, the unweighted mean for the non-SDQ studies was 0.34 for Parent and 0.46 for Teacher ratings. For the SDQ studies, Total Difficulties means were somewhat lower at 0.20 for Parents and 0.31 for Teachers. This comparison must be treated with caution as the non-SDQ effect sizes are based on pooling of results from a wide variety of measures of EBD.

\section{Discussion}

The analyses presented in this paper suggest that children and adolescents up to age 21 years with $\mathrm{HI}$ are likely to show an elevated rate of EBD. As rated on the SDQ by Parents and by Teachers (but not by the children themselves), these children and adolescents show an overall EBD score 0.23 of a SD above that of normally hearing children. The effect is more substantial for teacher ratings (0.34). There is an indication that this effect may decline with age but more studies (preferably longitudinal) are needed to adequately test for age-related changes. This pattern of a greater effect in teacher ratings is also found in the non-SDQ studies. In these studies, the effect sizes are slightly larger: namely 0.34 and 0.46 for Parent and Teacher ratings, respectively.

The findings from the SDQ studies suggest that Peer Problems showed the most marked and consistent increased risk of EBD. For Teacher ratings only, a significantly higher mean Conduct Problems score was obtained for children with HI. For Parent ratings only, there was a significant association between HI and elevated Emotional Symptoms. For all raters, there was no evidence that children with $\mathrm{HI}$ showed elevated levels of Hyperactivity. Parents report significantly less Prosocial Behaviour in children with HI.

The lower estimate of effect size in the SDQ studies might arise from a number of factors. First, the methods of measuring EBD might have an impact, e.g. in terms of the number and types of behaviour items included. Second, the adoption of a common large general population sample to provide an SDQ behaviour score for hearing children may also have reduced the effect size. In the non-SDQ studies, some of the control group scores are "super-normal", i.e. unexpectedly low (e.g. [45]) and therefore might inflate the effect size estimate. Third, a number of the non-SDQ studies were published much earlier than the SDQ studies, all of which were published after the year 2000. Consequently, a smaller effect size may reflect improvements in the provision for psychological support for children with $\mathrm{HI}$ or changes in educational provision and policy which resulted in fewer difficulties being reported in the later studies. Children in these SDQ studies may also have benefited from early detection and confirmation of hearing loss as a result of universal newborn hearing screening. Since such screening and early confirmation are associated with better language [113] and better language is associated with reduced EBD [1], this could have led to a reduction in EBD in more recent studies. However, a direct test of the effect of early confirmation on later behaviour failed to detect a benefit [107] perhaps because the associated improvement in language was only to a rather low level, e.g. mean aggregate receptive language $z$ score in children with early confirmed hearing impairments remained 1.76 SD below the mean score in the normally hearing comparison group.

The findings of Anmyr et al. [93] are a clear exception to the general pattern of the SDQ results. In that study the children with $\mathrm{HI}$ are rated as showing fewer EBD than controls. A distinctive feature of the sample in [93] was that all the children had received cochlear implants. The other study exclusively including children with cochlear implants was that by Huber and Kipman [103]. They too found no difference in parental ratings on the SDQ, although teachers in that study did report significantly more Peer Problems in the cochlear implant group 


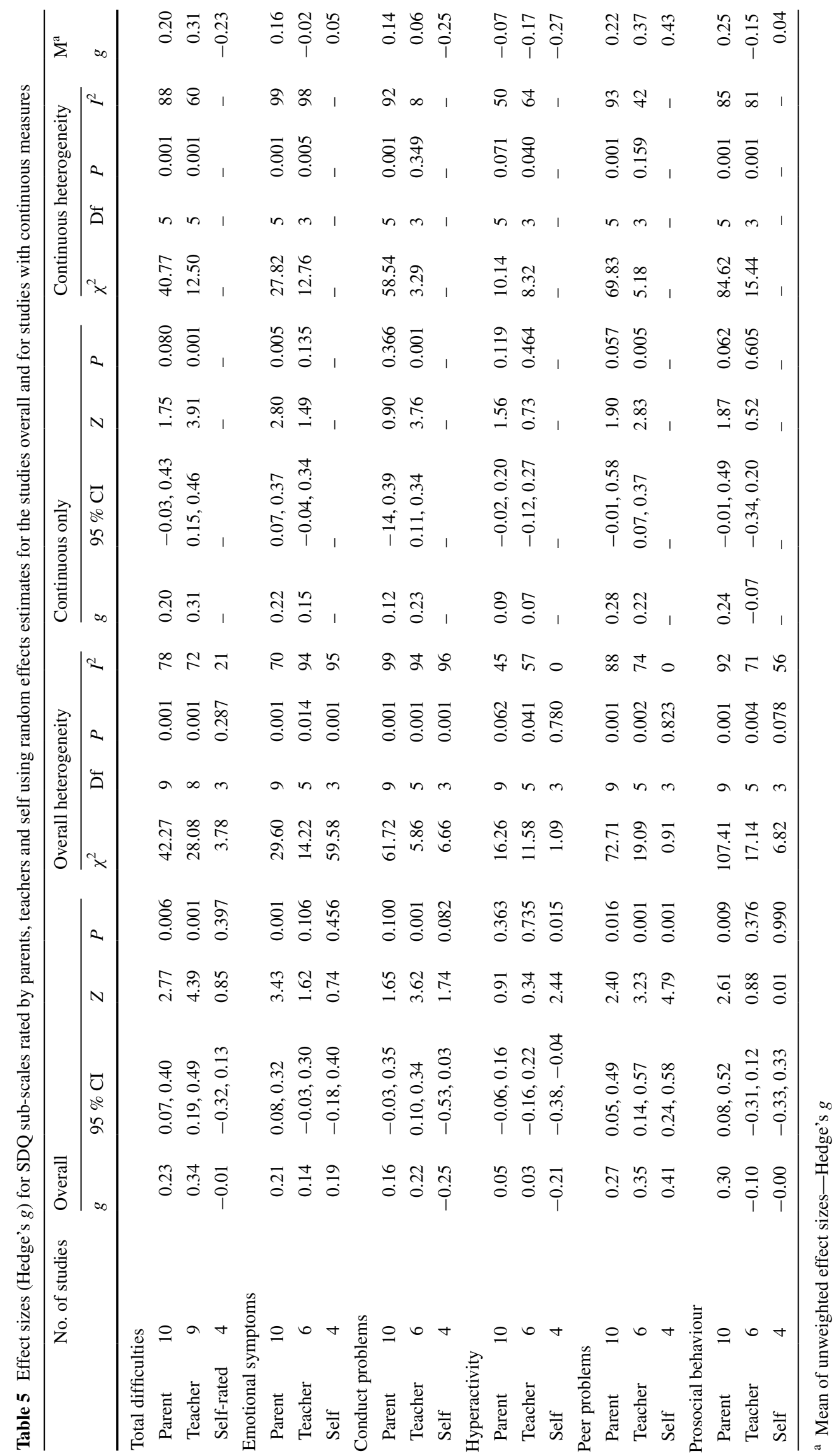


A SDQ Parent Rated Total Difficulties

Hedges' g, Random effects, $95 \% \mathrm{Cl}$

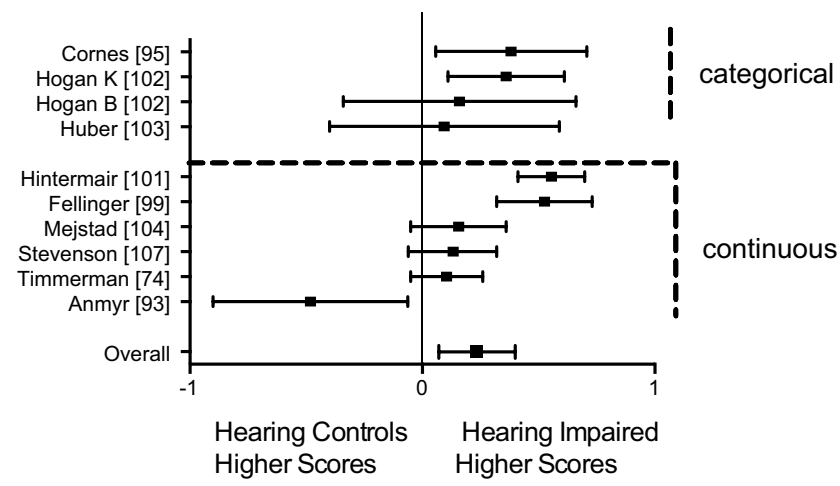

Overall effect size $(95 \% \mathrm{Cl})=0.23(0.07,0.40)$

Test for overall effect: $Z=2.77, p=0.006$

Continuous only effect size $(95 \% \mathrm{Cl})=0.20(-0.03,0.43)$

Test for Continuous only effect: $Z=1.75, p=0.25$

\section{SDQ Parent Rated Peer Problems} Hedges' g, Random effects, $95 \% \mathrm{Cl}$

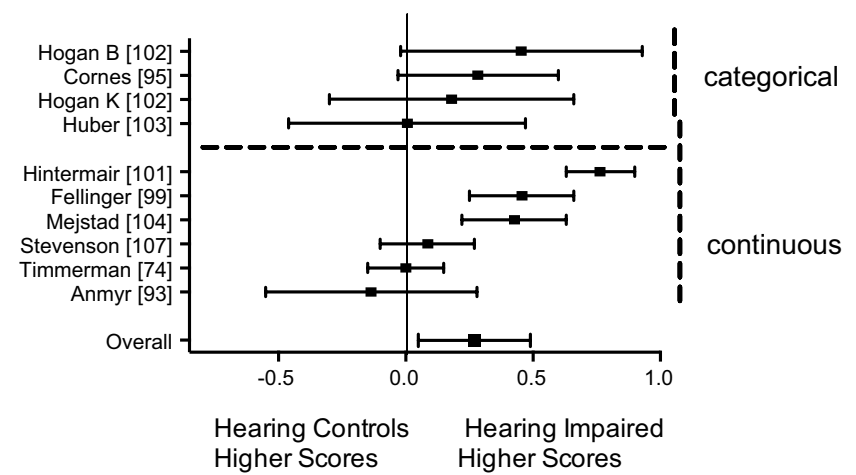

Overall effect size $(95 \% \mathrm{Cl})=0.27(0.05,0.49)$

Test for overall effect: $Z=2.40, p=0.016$

Continuous only effect size $(95 \% \mathrm{Cl})=.28(-.01, .58)$

Test for Continuous only effect: $Z=1.90, p=.057$
B SDQ Parent Rated Total Difficulties

Hedges' g, Random effects, $95 \% \mathrm{Cl}$

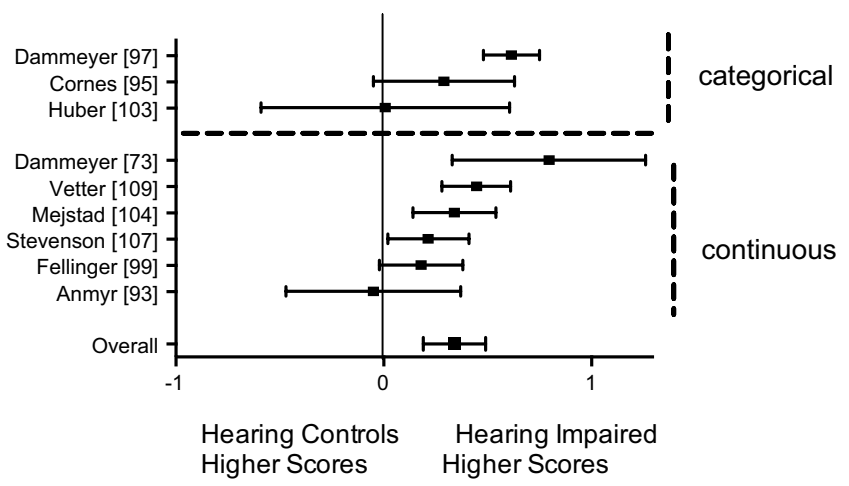

Overall effect size $(95 \% \mathrm{Cl})=0.34(0.19,0.49)$

Test for overall effect: $Z=4.39, p=0.001$

Continuous only effect size $(95 \% \mathrm{Cl})=0.31(.15, .46)$

Test for Continuous only effect: $Z=3.91, p=.001$

\section{SDQ Parent Rated Peer Problems Hedges' g, Random effects, $95 \% \mathrm{Cl}$}

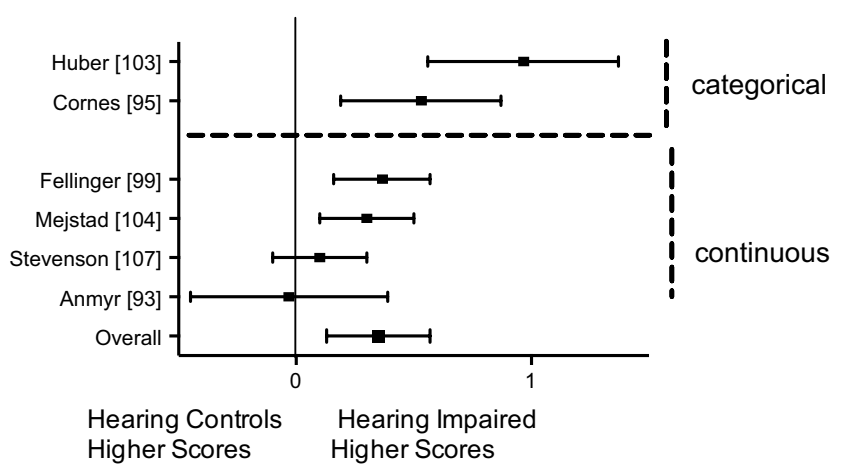

Overall effect size $(95 \% \mathrm{Cl})=0.35(0.14,0.57)$

Test for overall effect: $Z=3.23, p<0.001$

Continuous only effect size $(95 \% \mathrm{Cl})=0.22(.07, .37)$

Test for Continuous only effect: $Z=2.83, p=.005$

Fig. 3 Forest plots for SDQ Total Difficulties and Peer Problems rated by Parents and by Teachers differentiating studies using categorical and continuous scoring. Effect sizes are Hedges' $g$ with $95 \%$ confidence intervals estimated using a random effects model

compared to controls. The remainder of the SDQ studies had fewer than $33 \%$ of cases receiving cochlear implants. It remains unclear whether those treated with cochlear implants may have fewer EBD or whether specific cultural factors such as parental expectations about behaviour may have resulted in the anomalous findings reported in [93], as these authors suggest.

\section{Hyperactivity}

Our findings suggest no heightened risk for children with HI to present with symptoms of hyperactivity or inattention. This was somewhat surprising considering that there is some evidence for a possible link between $\mathrm{HI}$ and ADHD-type symptoms related to underlying cognitive abilities. Specifically, it has been shown that children with $\mathrm{HI}$ are more likely to have deficits in executive function and that scores on executive function were significantly related to Total Difficulties scores on the SDQ [81]. As attention and executive abilities are thought to be aspects of the underlying cognitive difficulties experienced by children with ADHD (see [114] and [115], respectively), it might be expected that children with HI would be likely to show a pattern of behaviour similar to ADHD.

However, evidence from studies using visually presented material to examine attention in $\mathrm{HI}$ participants is 
inconsistent. Tharpe et al. [45] found few differences between children with and without $\mathrm{HI}$ in visual attention performance. They suggested that the effects are influenced both by age and intelligence and differences between the groups disappeared when these factors were controlled statistically. By contrast, Mitchell and Quittner [38] reported significant attention deficits in children with $\mathrm{HI}$ on two of three attention tasks using the continuous performance test (CPT [116]). Performance on the CPT tasks was significantly associated with Parent and Teacher ratings of behaviour difficulties. However, the authors concluded that the attention problems in children with $\mathrm{HI}$ were not necessarily related to ADHD. Instead, they suggested that children with HI show a distinct pattern of impaired attention and problem behaviours. Furthermore, Quittner et al. [117] showed how the development of this pattern of impaired attention can be at least partially off-set by cochlear implantation. This was consistent with other evidence [118] which suggested that visual attention improves when children with $\mathrm{HI}$ are given cochlear implants.

There is no indication from the SDQ studies reviewed here that children with $\mathrm{HI}$ have a specific propensity to develop hyperactivity. Indeed the effect sizes for parent and teacher ratings are non-significant and for Self-ratings are in the opposite direction. This raises the question of why overviews of the earlier studies on children with HI have concluded that hyperactivity was a particularly salient feature of their behaviour.

There is a possibility that the SDQ is a less valid or less sensitive measure of hyperactivity or ADHD as it only relies on five items to assess this pattern of behaviour. However, studies of large general population samples in Europe [119] and in the USA [120] and of clinical samples of children with ADHD [121, 122] have supported the validity of the SDQ as a measure of hyperactivity. A summary of such data is given in a meta-analysis of 48 studies $(N=131,223)$ on the psychometric properties of the SDQ [123].

It appears then that earlier studies of ADHD-related behaviours in children with HI may have over-estimated such an association possibly as a result of the difficulties that have been noted in the assessment of such behaviour in deaf children, such as failure to follow directions being the consequence of hearing impairment rather than inattention [124].

\section{Mediating and risk factors}

It is important to note that the present meta-analysis does not directly examine the possible factors mediating the impact of $\mathrm{HI}$ on EBD but these need to be considered in interpreting the findings. It has been suggested that low non-verbal IQ [3, 45] and language impairment may be crucial mediators [5, 6]. The difficulties in language acquisition experienced by children with $\mathrm{HI}$ may contribute to the risk of EBD in a number of ways. The first is via a failure to effectively understand or communicate information about needs and wants with others. The second is via deficits in emotional and behavioural regulation that are, in part, dependent on language processing. These are interpersonal and intrapersonal processes respectively and children with HI may have deficits in either or both of these with consequently adverse effects on behaviour [14]. It has also been suggested that the language deficits in children with $\mathrm{HI}$ are related to intrapersonal cognitive processes such as attention [125] and executive function [126] that in turn create a vulnerability to poor behavioural regulation.

The optimal method for detecting risk factors, i.e. features that make a child with HI more likely to develop $\mathrm{EBD}$, is via a multiple regression moderator analysis based on the child as the unit of analysis [127]. The present metaanalysis only has the study as the unit of analysis and using a meta-regression tested whether age was a moderator of the effect of HI on EBD. It was not. The approach adopted by Theunissen [4] was to survey whether specific risk and protective factors had been found to relate to EBD within HI samples. Using this approach, age at detection and intervention of hearing loss, the presence of additional disabilities, communication skills, intelligence, type of school, and number of siblings were suggested as possible influences on EBD in children and adolescents with HI.

\section{Peer problems}

The review of the studies using the SDQ identifies Peer Problems as the area with the most difficulties for children with HI. Other studies reinforce this notion of peer relationships and friendships as being problematic for children with HI. Henggeler et al. [128] found that the mothers and the fathers of adolescents with HI, but not the adolescents themselves, rated their relationship with friends as showing more aggression than did the parents of hearing adolescents. Parents reported that their deaf children were socially isolated and did not participate in structured activities [2]. This effect was found for otherwise well-functioning children and not just for those with behaviour problems. A schoolbased study also reported that although not rejected by others, deaf pupils in mainstream schools may feel isolated [129]. As a result, they show lower self-esteem in relation to peer relationships [130]. One factor likely to be contributing to peer relationship difficulties is the delay in acquiring pragmatic language skills shown by children with HI [131].

There is some evidence that social skill training can have an enduring beneficial effect on peer relationships in deaf children [132]. Replication and extension of these findings on intervention are clearly needed as the findings in this review suggest that peer relationship problems may be a real risk for children with HI. Further research is necessary to illuminate the processes by which children with HI become more socially isolated; in particular into the role, 
difficulties in language ability are likely to play as a mediator in this association. The clinical and service implications of social and mental health problems in deaf children and adults have been recently reviewed [133].

Limitations on the study

As discussed above a major feature of the studies being reviewed was their heterogeneity in terms of factors such as age, severity of hearing loss, numbers of children with cochlear implants and types of control/comparison groups employed. There were also a wide range of methods used to measure EBD. This in part was addressed by separating studies applying the SDQ from those using other questionnaires. It is feature of all the studies reported here that they were reliant on partner, teacher or self-ratings on questionnaires to obtain assessment of EBD. It is uncertain what affect the absence of more clinically sensitive methods this might have on the level of EBD found in children with HI [134].

\section{Conclusions}

The analyses presented here confirm that children with $\mathrm{HI}$ are more likely to show EBD than other children. The effect may be less marked than earlier studies suggested. The ratings of EBD by teachers show the largest effect. There is no indication that $\mathrm{HI}$ is related to hyperactivity or ADHD-related behaviours. It is in the area of peer relationships that the most marked behaviour difficulties for children with HI are found.

Acknowledgments We would like to thank Dr. Maria Huber and Dr. Florian Juen for answering queries concerning their studies. We gratefully acknowledge the support of The Wellcome Trust that made this study possible. We thank also members of the Hearing Outcomes in Teenagers steering group for their advice; Hazel Blythe, Merle Mahon, Janet Peacock, Steve Powers, Emmanouela Terlektsi, Brian Yuen. The work reported here was undertaken as part of a study supported by The Wellcome Trust Grant Number 089251/Z/09/Z.

Conflict of interest On behalf of all authors, the corresponding author states that there is no conflict of interest.

Open Access This article is distributed under the terms of the Creative Commons Attribution License which permits any use, distribution, and reproduction in any medium, provided the original author(s) and the source are credited.

\section{References}

1. Stevenson J, McCann D, Watkin P, Worsfold S, Kennedy C, Hearing Outcomes Study Team (2010) The relationship between language development and behaviour problems in children with hearing loss. J Child Psychol Psychiatry 51:77-83
2. Vostanis P, Hayes M, Du Feu M, Warren J (1997) Detection of behavioural and emotional problems in deaf children and adolescents: comparison of two rating scales. Child Care Health Dev 23:233-246

3. Hindley PA, Hill PD, McGuigan S, Kitson N (1994) Psychiatric disorder in deaf and hearing impaired children and young people: a prevalence study. J Child Psychol Psychiatry 35:917-9344

4. Theunissen SCPM et al (2014) Psychopathology and its risk and protective factors in hearing-impaired children and adolescents a systematic review. JAMA Pediatr 168:170-177

5. Hindley P, Kroll L (1998) Theoretical and epidemiological aspects of attention deficit and overactivity in deaf children. $\mathrm{J}$ Deaf Stud Deaf Educ 3:64-72

6. Kelly D, Kelly B, Jones M, Moulton N, Verhulst S, Bell S (1993) Attention deficits in children and adolescents with hearing loss. Am J Dis Child 147:737-741

7. Van Eldik TT, Treffers PDA, Veerman JW, Verhulst FC (2004) Mental health problems of deaf Dutch children as indicated by parents' responses to the child behavior checklist. Am Ann Deaf 148:390-395

8. Van Gent T, Goedhart AW, Hindley PA, Treffers PDA (2007) Prevalence and correlates of psychopathology in a sample of deaf adolescents. J Child Psychol Psychiatry 48:950-958

9. Borenstein M, Hedges LV, Higgins JPT, Rothstein HR (2009) Introduction to meta-analysis. Wiley, Chichester

10. Goodman R (1997) The Strengths and Difficulties Questionnaire: a research note. J Child Psychol Psychiatry 38:581-586

11. Moeller MP (2007) Current state of knowledge: psychosocial development in children with hearing impairment. Ear Hear 28:729-739

12. Aplin DY (1985) Social and emotional adjustments of hearingimpaired children in special schools. J Br Assoc Teach Deaf 9:84-94

13. Aplin DY (1987) Social and emotional adjustments of hearingimpaired children in ordinary and special schools. Educ Res 29:56-64

14. Barker DH et al (2009) Predicting behavior problems in deaf and hearing children: the influences of language, attention, and parent-child communication. Dev Psychopathol 21:373-392

15. Bat-Chava Y, Deignan E (2001) Peer relationships of children with cochlear implants. J Deaf Stud Deaf Educ 6:186-199

16. Bat-Chava Y, Martin D, Kosciw JG (2005) Longitudinal improvements in communication and socialization of deaf children with cochlear implants and hearing aids: evidence from parental reports. J Child Psychol Psychiaty 46:1287-1296

17. Bizjak MC (2009) Understanding emotional health and psychological adjustment in students with or without a specific hearing deficiency. J Dev Phys Disabil 21:213-224

18. Freeman RD, Malkin SF, Hastings JO (1975) Psychosocial problems of deaf children and their families: a comparative study. Am Ann Deaf 120:275-304

19. Gallaudet Research Institute (2008) Regional and national summary report of data from the 2007-08 Annual Survey of Deaf and Hard of Hearing Children and Youth. Gallaudet Research Institute, Washington, DC

20. Keilmann A, Limberger A, Mann WJ (2007) Psychological and physical well-being in hearing-impaired children. Int J Pediatr Otorhinolaryngol 71:1747-1752

21. Kent BA (2003) Identity issues for hard-of-hearing adolescents aged 11, 13, and 15 in mainstream setting. J Deaf Stud Deaf Educ 8:315-324

22. King NJ, Mulhall J, Gullone E (1989) Fears in hearing-impaired and normally hearing children and adolescents. Behav Res Ther 27:577-580

23. Kouwenberg M, Rieffe C, Theunissen SCPM, Oosterveld P (2012) Pathways underlying somatic complaints in children and 
adolescents who are deaf or hard of hearing. J Deaf Stud Deaf Educ 17:319-332

24. Maes B, Grietens H (2004) Parent-reported problem behaviour among children with sensory disabilities attending elementary regular schools. J Dev Phys Disabil 16:361-375

25. Polat F (2003) Factors affecting psychosocial adjustment of deaf students. J Deaf Stud Deaf Educ 8:325-339

26. Andersson G, Olsson E, Rydell A-M, Larsen HC (2000) Social competence and behaviour problems in children with hearing impairment. Audiology 39:88-92

27. Arnold P, Atkins J (1991) The social and emotional adjustment of primary hearing-impaired children integrated in primary schools. Educ Res 33:223-228

28. Brubaker RG, Szakowski A (2000) Parenting practices and behavior problems among deaf children. Child Fam Behav Ther 22:13-28

29. Cornes A, Rohan MJ, Napier J, Rey JM (2006) Reading the signs: impact of signed versus written questionnaires on the prevalence of psychopathology among deaf adolescents. Aust N Z J Psychiatry 40:665-673

30. Davis JM, Elfenbein J, Schum R, Bentler R (1986) Effects of mild and moderate hearing impairments on language, educational and psychosocial behavior of children. J Speech Hear Disord 51:53-62

31. Edwards L, Khan S, Broxholme C, Langdon D (2006) Exploration of the cognitive and behavioural consequences of paediatric cochlear implantation. Cochlear Implants Int 7:61-76

32. Fundudis T, Kolvin I, Garside R (1979) Speech retarded and deaf children: their psychological development. Academic Press, London

33. Furstenberg K, Doyal G (1994) The relationship between emotional-behavioral functioning and personal characteristics on performance outcomes of hearing impaired students. Am Ann Deaf 139:410-414

34. Kammerer E (1988) Kinderpsychiatrische Aspekte der schweren Hörschädigung [Child psychiatric aspects of severe hearing impairment]. Ferdinand Enke Verlag, Stuttgart

35. Konuk N, Erdogan A, Atik L, Ugur MB, Simsekyilmaz O (2006) Evaluation of behavioral and emotional problems in deaf children by using the child behavior checklist. Neurol Psychiatry Brain Res 13:59-64

36. Kouwenberg M, Rieffe C, Theunissen CPM (2011) Intrapersonal and interpersonal factors related to self reported symptoms of depression in DHH youth. Int J Mental Health Deaf 1:46-57

37. Li H, Prevatt F (2010) Deaf and hard of hearing children and adolescents in China: their fears and anxieties. Am Ann Deaf 155:458-466

38. Mitchell TV, Quittner AL (1996) Multimethod study of attention and behaviour problems in hearing-impaired children. $\mathrm{J}$ Clin Child Psychol 25:83-96

39. Prior MR, Glazner J, Sanson A, Debelle G (1988) Research note: temperament and behavioural adjustment in hearing impaired children. J Child Psychol Psychiatry 29:209-216

40. Quittner AL, Barker DH, Cruz I, Snell C, Grimley ME, Botteri M, The CDaCI Investigative Team (2010) Parenting stress among parents of deaf and hearing children: associations with language delays and behavior problems. Parent Sci Pract 10:136-155

41. Remine MD, Brown PM (2010) Comparison of the prevalence of mental health problems in deaf and hearing children and adolescents in Australia. Aust N Z J Psychiatry 44:351-357

42. Rutter M, Graham P, Yule W (1970) A neuropsychiatric study in childhood. Clinics in developmental medicine Nos. 35/36. Spastics International Medical Publications, London

43. Sahli S, Arslan U, Belgin E (2009) Depressive emotioning in adolescents with cochlear implant and normal hearing. Int $\mathbf{J}$ Pediatr Otorhinolaryngol 73:1774-1779
44. Sinkkonen J (1994) Hearing impairment, communication and personality development. Unpublished doctoral dissertation. University of Helsinki, Helsinki

45. Tharpe AM, Ashmead DH, Rothpletz AM (2002) Visual attention in children with normal hearing, children with hearing aids, and children with cochlear implants. J Speech Lang Hear Res 45:403-413

46. Theunissen SCPM, Rieffe C, Kouwenberg M, Soede W, Briaire JJ, Frijns JHM (2011) Depression in hearing-impaired children. Int J Pediatr Otorhinolaryngol 75:1313-1317

47. Theunissen SCPM et al (2012) Anxiety in children with hearing aids or cochlear implants compared to normally hearing controls. Laryngoscope 12:654-659

48. Theunissen SCPM et al (2014) Behavioral problems in schoolaged hearing-impaired children: the influence of sociodemographic, linguistic, and medical factors. Eur Child Adolesc Psychiatry 23:187-196

49. Topol D, Girard N, St Pierre L, Tucker R, Vohr B (2011) The effects of maternal stress and child language ability on behavioral outcomes of children with congenital hearing loss at 18-24 months. Early Hum Dev 87:807-811

50. van Eldik TT (1994) Behavior problems with deaf Dutch boys. Am Ann Deaf 139:394-399

51. Van Eldik TT (2005) Mental health problems of Dutch youth with hearing loss as shown on the Youth Self-Report. Am Ann Deaf 150:11-16

52. Wake M, Hughes EK, Poulakis Z, Collins C, Rickards FW (2004) Outcomes of children with mild-profound congenital hearing loss at 7-8 years: a population study. Ear Hear 25:1-8

53. Watt JD, Davis FE (1991) The prevalence of boredom proneness and depression among profoundly deaf residential school adolescents. Am Ann Deaf 136:409-413

54. Stott DH (1974) The social adjustment of children: manual of the Bristol Social Adjustment Guides, 5th edn. Hodder and Stoughton, London

55. Rutter M (1967) A children's behaviour questionnaire for completion by teachers: preliminary findings. J Child Psychol Psychiatry 8:1-11

56. Achenbach TM, Edelbrock C (1983) Manual for the Child Behavior Checklist and revised Child Behavior Profile. University of Vermont Department of Psychiatry, Burlington

57. Achenbach TM, Edelbrock C (1986) Manual for the Teacher's Report Form and teacher version of the Child Behavior Profile. University of Vermont Department of Psychiatry, Burlington

58. Rutter M, Tizard J, Whitmore K (eds) (1970) Education, health and behaviour. Longmans, London

59. Goyette CH, Conners CK, Ulrich RF (1978) Normative data on revised Conners parent and teacher rating scales. J Abnorm Child Psychol 6:221-236

60. Achenbach TM (1991) Manual for the YSR and 1991 profile. University of Vermont Department of Psychiatry, Burlington

61. Achenbach TM (2000) Child Behavior Checklist 1.5-5. ASEBA, Burlington

62. Achenbach TM, Rescorla LA (2001) Manual for the ASEBA school-age forms and profiles. University of Vermont, Research Center for Children, Youth and Families, Burlington

63. Kovacs M (1985) The Childrens' Depression Inventory (CDI). Psychopharmacol Bull 21:995-998

64. Gadow K, Sprafkin J (1994) Child Symptom Inventories. Checkmate plus. Stony Brook, NY

65. Beck AT, Rush AJ, Shaw BE, Emery G (1979) Cognitive therapy of depression. Guilford, New York

66. Reynolds CR, Richmond BO (1985) Revised Children's Manifest Anxiety Scale. Western Psychological Services, Los Angeles

67. Rosenberg M (1965) Society and the adolescent self-image. Princeton University Press, Princeton 
68. Eyberg S, Ross AW (1978) Assessment of child behavior problems: the validation of a new inventory. J Clin Child Psychol 7:113-116

69. Behar L, Stringfield SA (1974) Behaviour rating scale for the preschool child. Dev Psychol 10:601-610

70. Sawyer M, Arney F, Baghurst P et al (2001) The mental health of young people in Australia: key findings from the child and adolescent component of the national survey of mental health and wellbeing. Aust N Z J Psychiatry 35:806-814

71. Moher D, Liberati A, Tetzlaff J, Altman DG, The PRISMA Group (2009) Preferred reporting items for systematic reviews and meta-analyses: the PRISMA statement. PLoS Med 6(6):e1000097. doi:10.1371/journal.pmed1000097

72. van Driel ML, De Sutter A, De Maeseneer J, Christiaens T (2009) Searching for unpublished trials in Cochrane reviews may not be worth the effort. J Clin Epidemiol 62:838-844

73. Dammeyer J (2012) Children with Usher syndrome: mental and behavioural disorders. Behav Brain Funct 8:16. doi:10.1186/1744-9081-8-16

74. Timmerman A, Meesters C, Anteunis L, Chenault M (2007) Level of psychosocial adaptation in young school children with otitis media. Int J Pediatr Otorhinolaryngol 71:1843-1848

75. Fellinger J, Holzinger D, Beitel C, Laucht M, Goldberg DP (2009) The impact of language skills on mental health in teenagers with hearing impairments. Acta Psychiatr Scand 120:153-159

76. Fellinger J, Holzinger D, Sattel H, Laucht M, Goldberg D (2009) Correlates of mental health disorders among children with hearing impairments. Dev Med Child Neurol 51:635-641

77. Fellinger J, Holzinger D (2011) Enhancing resilience to mental health disorders in deaf school children. In: Zand DH, Pierce KJ (eds) Resilience in deaf children: adaptation through emerging adulthood. Springer, New York, pp 230-257

78. Garg S et al (2013) Autism and other psychiatric comorbidity in neurofibromatosis type 1: evidence from a population-based study. Dev Med Child Neurol 55:139-145

79. Gurney JG, Tersak JM, Ness KK, Landier W, Matthay KK, Schmidt ML (2007) Hearing loss, quality of life, and academic problems in long-term neuroblastoma survivors: report from the Children's Oncology Group. Pediatrics 120:E1229-E1236

80. Hintermair M (2006) Socio-emotional problems among hearing-impaired children-initial results of the German version of the Strenghts and Difficulties Questionnaire (SDQ-D). Z Kinde Jugendpsychiatr Psychother 34:49-61

81. Hintermair M (2013) Executive functions and behavioral problems in deaf and hard-of-hearing students at general and special schools. J Deaf Stud Deaf Educ 18:344-359

82. Hutchison T, Gordon D (2005) Ascertaining the prevalence of childhood disability. Child Care Health Dev 31:99-107

83. Ketelaar L, Rieffe C, Wiefferink CH, Frijns JHM (2013) Social competence and empathy in young children with cochlear implants and with normal hearing. Laryngoscope 123:518-523

84. Marret $S$ et al (2009) Special outpatient services at 5 and 8 years in very-preterm children in the EPIPAGE study. Arch Pediatr 16:S17-S27

85. McCormack J, Harrison LJ, McLeod S, McAllister L (2011) A nationally representative study of the association between communication impairment at 4-5 years and children's life activities at 7-9 years. J Speech Lang Hear Res 54:1328-1348

86. Moller K (2003) Deaf blindness: a challenge for assessment-is the ICF a useful tool? Int J Audiol 42:S140-S142

87. Muigg F, Nekahm-Heis D, Juen F (2010) Hearing impaired children in regular schools-self-concept, integration experience, psycho-social aspects and educational frameworks. Sprache-Stimme-Gehor 34:237-242

88. Rieffe C, Ketelaar L, Wiefferink CH (2010) Assessing empathy in young children: construction and validation of an Empathy Questionnaire (EmQue). Pers Individ Diff 49:362-367
89. Saigal S et al (2007) Comparison of current health, functional limitations, and health care use of young adults who were born with extremely low birth weight and normal birth weight. Pediatrics 119:E562-E573

90. St Clair MC, Pickles A, Durkin K, Conti-Ramsden G (2011) A longitudinal study of behavioral, emotional and social difficulties in individuals with a history of specific language impairment (SLI). J Commun Disord 44:186-199

91. Sumpter R, Brunklaus A, McWilliam R, Dorris L (2011) Health-related quality-of-life and behavioural outcome in survivors of childhood meningitis. Brain Inj 25:1288-1295

92. Watson L, Brown PM (2012) Editorial. Deaf Educ Int 14:121

93. Anmyr L, Larsson K, Olsson M, Freijd A (2012) Strengths and difficulties in children with cochlear implants-comparing selfreports with reports from parents and teachers. Int $\mathrm{J}$ Pediatr Otorhinolaryngol 76:1107-1112

94. Meltzer H, Gatward R, Goodman R, Ford F (2000) Mental health of children and adolescents in Great Britain. The Stationery Office, London

95. Cornes AJ, Brown PM (2012) Mental health of Australian deaf adolescents: an investigation using an Auslan version of the Strengths and Difficulties Questionnaire. Deaf Educ Int 14:161-175

96. Goodman R (2001) Psychometric properties of the Strengths and Difficulties Questionnaire. J Am Acad Child Adolesc Psychiatry 40:1337-1345

97. Dammeyer J (2010) Psychosocial development in a Danish population of children with cochlear implants and deaf and hard-of-hearing children. J Deaf Stud Deaf Educ 15:50-58

98. Smedje H, Broman JE, Hetta J, von Knorring AL (1999) Psychometric properties of a Swedish version of the "Strengths and Difficulties Questionnaires". Eur Child Adolesc Psychiatry 8:63-70

99. Fellinger J, Holzinger D, Sattel H, Laucht M (2008) Mental health and quality of life in deaf pupils. Eur Child Adolesc Psychiatry 17:414-423

100. Woerner W, Becker A, Rothenberge A (2004) Normative data and scale properties of the German parent SDQ. Eur Child Adolesc Psychiatry 13 (Suppl 2)(2):3-10

101. Hintermair M (2007) Prevalence of socioemotional problems in deaf and hard of hearing children in Germany. Am Ann Deaf 152:320-330

102. Hogan A, Phillips RL, Howard D, Yienprugsawan V (2014) Psychosocial outcomes of children with ear infections and hearing problems: a longitudinal study. BMC Pediatr 14:65-73

103. Huber M, Kipman U (2011) The mental health of deaf adolescents with cochlear implants compared to their hearing peers. Int J Audiol 50:146-154

104. Mejstad L, Heiling K, Svedin CG (2009) Mental health and self-image among deaf and hard of hearing children. Am Ann Deaf 153:504-515

105. Van Roy B, Grøholt B, Heyerdahl S, Clench-Aas J (2006) Self-reported strengths and difficulties in a large Norwegian population 10-19 years: age- and gender-specific results of the extended SDQ questionnaire. Eur Child Adolesc Psychiatry 15:189-198

106. Koskelainen M, Sourander A, Vauras M (2001) Self-reported strengths and difficulties in a community sample of Finnish adolescents. Eur Child Adolesc Psychiatry 10:180-185

107. Stevenson J et al (2011) The effect of early confirmation of hearing loss on the behaviour in middle childhood of children with bilateral hearing impairment. Dev Med Child Neurol 53:269-274

108. Simpson GA, Bloom B, Cohen RA, Blumberg S, Bourdon KH (2005) US children with emotional and behavioral difficulties: data from the 2001, 2002, and 2003 National Health Interview Surveys. National Center for Health Statistics, Hyattsville

109. Vetter A, Loehle E, Bengel J, Burger T (2010) The integration experience of hearing impaired elementary school students 
in separated and integrated school settings. Am Ann Deaf 155:369-376

110. Osburn HG, Callender J (1992) A note on the sampling variance of the mean uncorrected correlation in meta-analysis and validity generalization. J Appl Psychol 77:115-122

111. Harris RJ, Bradburn MJ, Deeks JJ, Harbord RM, Altman DG, Sterne JAC (2008) Metan: fixed- and random-effects meta-analysis. Stata J 8:3-28

112. Harbord RM, Higgins JPT (2008) Meta-regression in Stata. Stata J 8:493-519

113. Kennedy CR et al (2006) Language ability after early detection of permanent childhood hearing impairment. N Engl J Med 354:2131-2214

114. Huang-Pollock CL, Karalunas SL, Tam H, Moore AN (2012) Evaluating vigilance deficits in ADHD: a meta-analysis of CPT performance. J Abnorm Psychol 121:360-371

115. Lambek R, Tannock R, Dalsgaard S, Trillingsgaard A, Damm D, Thomsen PH (2011) Executive dysfunction in school-age children with ADHD. J Atten Disord 15:646-655

116. Gordon M (1983) The Gordon Diagnostic System. Gordon Systems, Boulder

117. Quittner AL et al (2007) Improvements in visual attention in deaf infants and toddlers after cochlear implantation. Audiol Med 5:242-249

118. Horn DL, Davis RAO, Pisoni DB, Miyamoto RT (2005) Development of visual attention skills in prelingually deaf children who use cochlear implants. Ear Hear 26:389-408

119. Van Roy B, Veenstra M, Clench-Aas J (2008) Construct validity of the five-factor Strengths and Difficulties Questionnaire (SDQ) in pre-, early, and late adolescence. J Child Psychol Psychiatry 49:1304-1312

120. He J-P, Burstein M, Schmitz A, Merikangas KR (2013) The Strengths and Difficulties Questionnaire (SDQ): the factor structure and scale validation in US adolescents. J Abnorm Child Psychol 41:583-595

121. Becker A et al (2006) Psychopathological screening of children with ADHD: Strengths and Difficulties Questionnaire in a pan-European study. Eur Child Adolesc Psychiatry 15(Suppl 1):56-62
122. Becker A, Woerner W, Hasselhorn M, Banaschewski T, Rothenberger A (2004) Validation of the parent and teacher SDQ in a clinical sample. Eur Child Adolesc Psychiatry 13(Suppl 2): $11-16$

123. Stone LL, Otten R, Engels RCME, Vermulst AA, Janssens JMAM (2010) Psychometric properties of the parent and teacher versions of the Strengths and Difficulties Questionnaire for 4- to 12-year-olds: a review. Clin Child Fam Psychol Rev 13:254-274

124. Kelly D, Forney J, Parker-Fisher S, Jones M (1993) Evaluating and managing attention deficit disorder in children who are deaf or hard of hearing. Am Ann Deaf 138:349-357

125. Dye M, Bavelier D (2010) Attentional enhancements and deficits in deaf populations: an integrative review. Restor Neurol Neurosci 28:181-192

126. Corina D, Singleton J (2009) Developmental social cognitive neuroscience: insights from deafness. Child Dev 80:952-967

127. Holmbeck GN (1997) Toward terminological, conceptual, and statistical clarity in the study of mediators and moderators: examples from the child-clinical and pediatric psychology literatures. J Consult Clin Psych 65:599-610

128. Henggeler SW, Watson SM, Whelan JP (1990) Peer-relations of hearing-impaired adolescents. J Pediatr Psychol 15:721-731

129. Nunes T, Pretzlik U, Olsson J (2001) Deaf children's social relationships in mainstream schools. Deaf Educ Int 3:123-136

130. Theunissen SCPM (2014) Self-esteem in hearing-impaired children: the influence of communication, education, and audiological characteristics. PLoS ONE 9:e94521

131. Goberis D, Beams D, Dalpes M, Abrisch A, Baca R, YoshinagaItano C (2012) The missing link in language development of deaf and hard of hearing children: pragmatic language development. Semin Speech Lang 33:297-309

132. Antia SD, Kreimeyer KH (1997) The generalization and maintenance of the peer social behaviors of young children who are deaf or hard of hearing. Lang Speech Hear Serv Sch 28:59-69

133. Fellinger J, Holzinger D, Pollard R (2012) Mental health of deaf people. Lancet 379(9820):1037-1044

134. Hindley P (1997) Psychiatric aspects of hearing impairments. J Child Psychol Psychiatry 38:101-117 